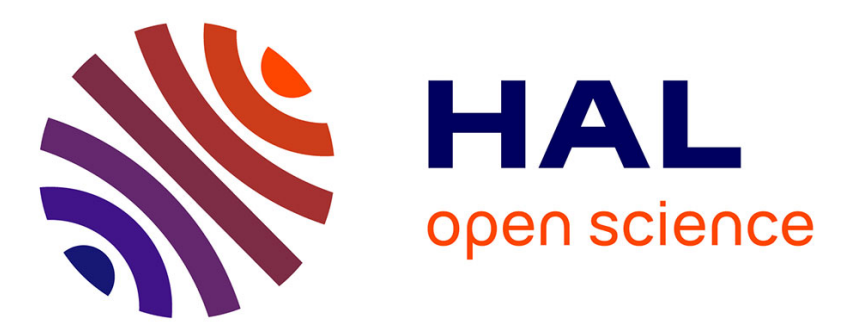

\title{
Characterization and quantification of active faulting in the Roer valley rift system based on high precision digital elevation models
}

\author{
Laurent Michon, R. T. van Balen
}

\section{To cite this version:}

Laurent Michon, R. T. van Balen. Characterization and quantification of active faulting in the Roer valley rift system based on high precision digital elevation models. Quaternary Science Reviews, 2005, 24, pp.457-474. 10.1016/j.quascirev.2003.11.009 . hal-01382030

\section{HAL Id: hal-01382030 \\ https://hal.univ-reunion.fr/hal-01382030}

Submitted on 4 Nov 2016

HAL is a multi-disciplinary open access archive for the deposit and dissemination of scientific research documents, whether they are published or not. The documents may come from teaching and research institutions in France or abroad, or from public or private research centers.
L'archive ouverte pluridisciplinaire HAL, est destinée au dépôt et à la diffusion de documents scientifiques de niveau recherche, publiés ou non, émanant des établissements d'enseignement et de recherche français ou étrangers, des laboratoires publics ou privés. 


\title{
Characterization and quantification of active faulting in the Roer valley rift system based on high precision digital elevation models
}

\author{
Laurent Michon $^{\mathrm{a}, \mathrm{b}, *}$, Ronald T. Van Balen ${ }^{\mathrm{c}}$ \\ ${ }^{\mathrm{a}}$ TNO-NITG, Department of Geo-Energy, P.O. Box 80015, 3508 TA Utrecht, The Netherlands \\ ${ }^{\mathrm{b}}$ Geologisches Institut, Freiburg Universität, Albertstr. 23b, 79104 Freiburg i. Br., Germany \\ c Department of Quaternary geology and Geomorphology, Vrije Universiteit Amsterdam, De Boelelaan 1085, 1081 HV Amsterdam, The \\ Netherlands
}

\begin{abstract}
The Roer valley rift system (RVRS) is located in the northern prolongation of the upper Rhine Graben. During the Cenozoic, the evolution of the RVRS was influenced by two different rift systems situated in the North and in the South (the North Sea rift system and the West European rift system, respectively). During the last decades, moderate seismicity revealed the continuous activity of the graben border faults (the Peel Boundary fault zone -PBFZ- and the Feldbiss fault zone-FFZ-). We use a high precision digital elevation model (DEM) to characterize and quantify the present-day deformation along these faults. The fault pattern shows similarity to a strike-slip structure. However, analysis of the DEM reveals that the Recent to Quaternary formations and landforms affected by the fault activity are only vertically offset. This suggests a pure normal faulting mode for the main border faults and a direction of extension perpendicular to the graben (i.e., NE-SW). Quantification of the offset dated markers allows the determination of the displacement rates along the fault segments. In the southeastern part of the RVRS, the vertical displacement rates inferred for the FFZ and the southeastern PBFZ range between 55 and $65 \mathrm{~mm} / \mathrm{ky}$ and around $65 \mathrm{~mm} / \mathrm{ky}$, respectively. In contrast, the displacement rates determined for the northwestern segment of the PBFZ are around $200 \mathrm{~mm} / \mathrm{ky}$. We explain these differences between the northwestern and southeastern parts of the RVRS by the large-scale geometry of the graben, the RVRS being symmetric in the south-east and asymmetric (half-graben) in the north-west. The deformation is accommodated by two border faults (FFZ and the south-eastern part of the PBFZ) in the south-east and by only one fault in the north-west (the north-western segment of the PBFZ). In addition, the thickness of the Neogene main depocentre in the northwestern half of the RVRS indicates a larger amount of extension in this part of the graben than in the south-east. The combination of the graben geometry and the amount of extension can explain the differences in the displacement rate.
\end{abstract}

(C) 2004 Elsevier Ltd. All rights reserved.

\section{Introduction}

In the past decades, the occurrence of two major earthquakes in the Roer valley rift system (RVRS) (Roermond in 1992, $M_{\mathrm{b}}=5,8$ and Aachen in 2002, $\left.M_{\mathrm{b}}=4,9\right)$ demonstrated that this rift system is one of the most active European rift structures. Studies of the

\footnotetext{
*Corresponding author. Laboratoire des Sciences de 1 a Terre de 1 'Universitede 1 a Réunion, Université de 1 a Réunion, 15 rue René Cassin, 97715 Saint Denis cedex 9, France. Tel.: +262-262-93-86-82; fax: + 262-262-93-82-66.

E-mail address: laurent.michon@univ-reunion.fr(L. Michon).
}

recent deformation associated with the fault activity indicate that this seismicity is part of a deformation process which extends at the graben scale (e.g., Van den Berg, 1994; Camelbeeck and Meghraoui, 1998; Houtgast and Van Balen, 2000). It is generally accepted that the present-day dynamics of the RVRS is induced by the Alpine collision (e.g., Ziegler, 1990). The resulting deformation has mainly been interpreted as dominated by a NW-SE strike slip motion, where the RVRS corresponds to a pull-apart graben (Kooi et al., 1991; Van den Berg, 1994). In such a model, the graben border faults are expected to be strike-slip faults, as proposed by Van den Berg (1994). However, this interpretation is 
in disagreement with the present-day local stress field (NE-SW pure extension) inferred from earthquake focal mechanisms (Plenefish and Bonjer, 1997). To clarify this debate, we focus our study on the present-day deformation along the main fault zones of the RVRS. We use a high precision digital elevation models (DEM) in order to characterize the active faults, to quantify the deformation and to determine the origin of the present-day dynamics.

The DEMs are located on the most active faults of the RVRS where the denser and stronger seismic activity was recorded (i.e., the peel boundary fault zone -PBFZand the Feldbiss fault zone-FFZ-) (Houtgast and Van Balen, 2000). Two of the DEMs are situated on the northwestern and southeastern segments of the PBFZ; the third area is located on the FFZ.

The goal of this article is (1) to determine precisely the geometry of the active faults, and (2) to quantify the vertical and/or lateral offsets related to the fault activity and the displacement rates along the faults of the RVRS. We integrate our results at a crustal scale in order to understand the strong variations of the displacement rates between the southeastern and northwestern parts of the RVRS.

\section{Geological setting}

To the north of the upper Rhine graben, the RVRS corresponds with the northern segment of the West European Rift (Ziegler, 1988; Michon et al., 2003) (Fig. 1). The Cenozoic RVRS developed upon the pre-existing basins of Carboniferous (Campine foreland basin) and Mesozoic (rift) age. It is structurally related closely to the Mesozoic basin. During the Mesozoic, the area was characterized by several periods of subsidence and inversion, which have reactivated the Variscan faults (Ziegler, 1990; Zijerveld et al., 1992; Winstanley, 1993; Geluk et al., 1994). During the Cenozoic, the RVRS was affected by two periods of inversion named the Laramide phase (early Paleocene) and the Pyrenean phase (late Eocene-early Oligocene) and by continuous subsidence since the beginning of the Oligocene (Geluk et al., 1994; Michon et al., 2003). The subsidence analysis combined with the study of $2 \mathrm{D}$ seismic lines allows the distinction of two successive periods of subsidence. During the Oligocene, an ESE-WNW extension has induced a local subsidence in the southeastern part of the RVG, leading to the development of narrow depocentres (Michon et al., 2003). In contrast, during the Miocene-Quaternary evolution, the subsidence has mainly affected the northwestern part of the graben with the formation of a large depocentre. The shape of the depocentre and the geometry of the Miocene faults were recently interpreted as the result of a NE-SW extension (Michon et al., 2003).

The RVRS is part of the lower Rhine embayment. From south-west to north-east, it consists of the Campine Block, the Roer valley graben (RVG) and the Peel Block (Fig. 1). The graben, which is $20 \mathrm{~km}$ wide and $130 \mathrm{~km}$ long, was controlled by the multi-stage activity of several major fault zones (PBFZ, Veldhoven fault zone, Rijen fault zone and FFZ) of Mesozoic or probably of older age. The PBFZ is a NW-SE oriented

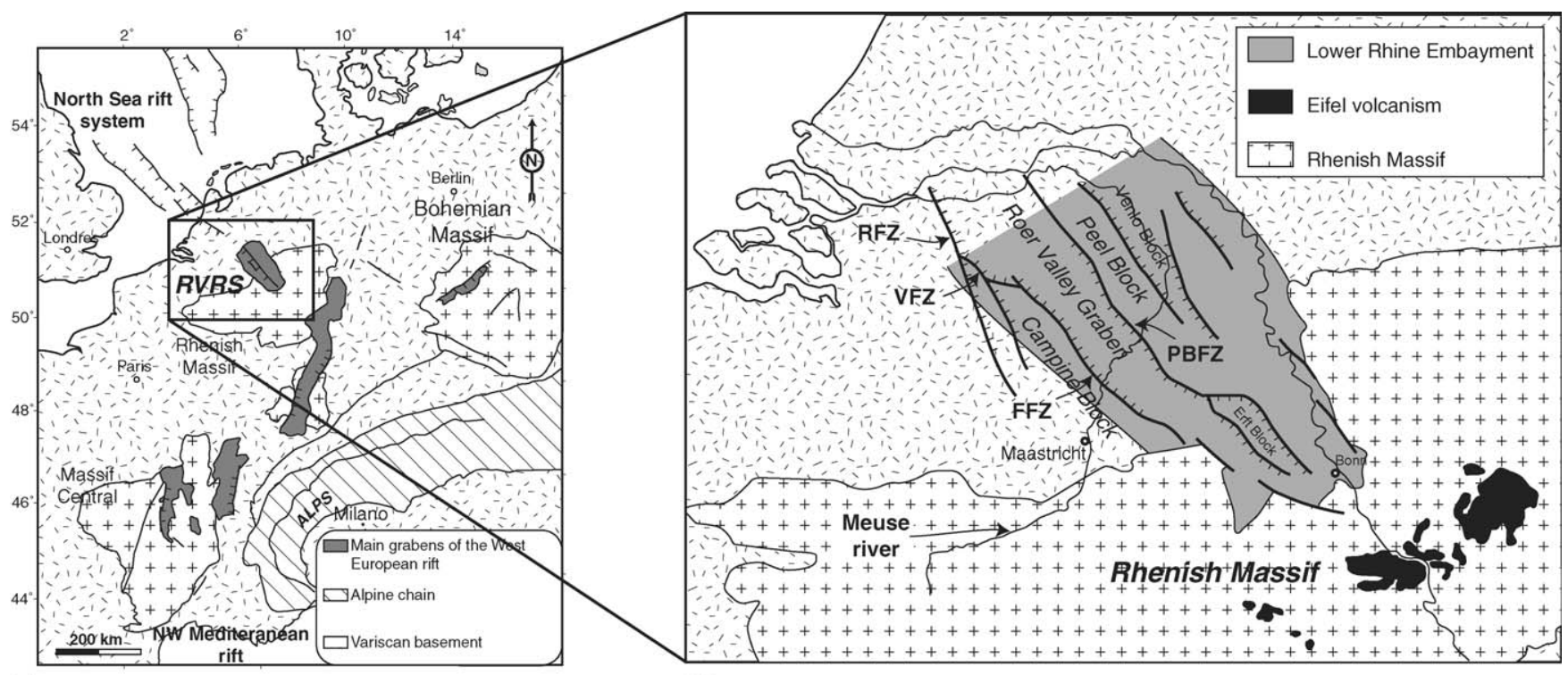

(a)

(b)

Fig. 1. Location map of the Roer valley rift system (RVRS) within the West European platform. (a) The RVRS corresponds to the northern segment of the West European rift, which was mainly formed during the Oligocene-Early Miocene period. During the Mesozoic and the Early Tertiary, the RVRS was the southern end of the North Sea rift system. (b) Tectonic map of the RVRS and the Lower Rhine Embayment. The Roer Valley graben is bounded in the North by the PBFZ, and in the South by the FFZ, the RFZ and the Veldhoven fault zone (VFZ). 

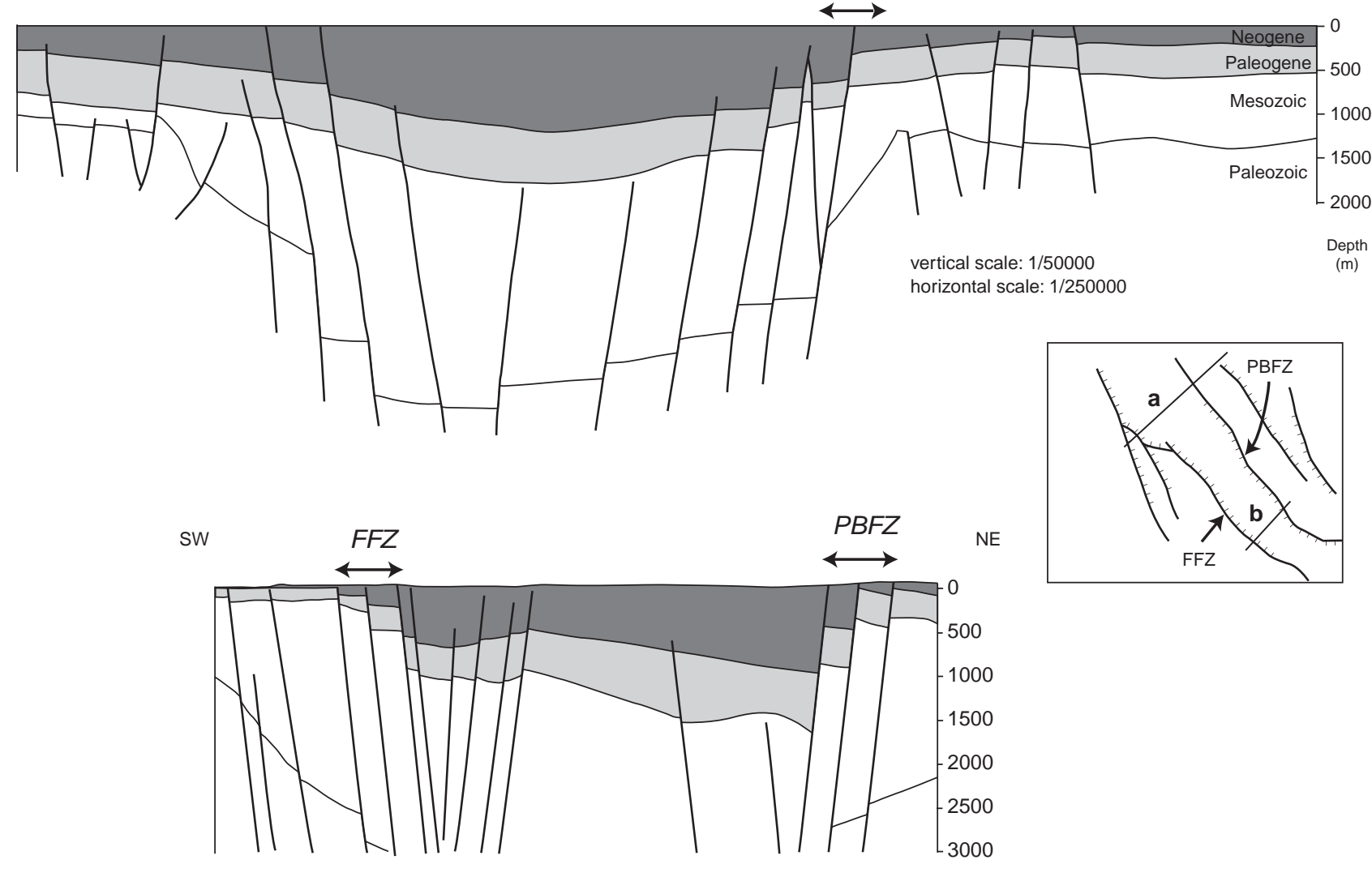

(b) horizontal scale: $1 / 250000$

Fig. 2. Synthetic cross sections based on seismic data perpendicular to the RVRS located in the northwestern (a) and the southeastern (b) parts of the graben.

$100 \mathrm{~km}$ long narrow deformation zone composed of the peel boundary fault and several secondary faults. In the southeastern part of the RVRS, the FFZ corresponds to the southwestern limit of the graben. This fault zone is $80 \mathrm{~km}$ long and is mainly composed of the Feldbiss fault, the Geleen fault and the Heerlerheide fault. Synthetic cross sections deduced from 2D seismic lines reveal that the geometry of the graben changes between the northern and southern parts (Fig. 2). In the north, the RVG is an asymmetric graben (half-graben) bounded by a major fault in the northeast (i.e., the PBFZ). The thickness of the tertiary sediments progressively decreases towards the southwest and is slightly affected by small secondary faults (i.e. the Rijen fault). In contrast, in its southern part, the RVG is a symmetric graben (full-graben) limited by two important faults located on each side. In this part, the offsets at the PBFZ $(\sim 1000 \mathrm{~m})$ and the FFZ $(\sim 600 \mathrm{~m})$ are of the same order of magnitude.

Several studies based on geomorphological and DEM analysis allowed the determination of the Quaternary faults in the RVRS (e.g., Van den Berg et al., 1994; Houtgast and Van Balen, 2000). Analysis of gradient maps (i.e., slope maps) inferred from DEMs with a
$100 \mathrm{~m}$ step highlighted the occurrence of three main fault orientations (NW-SE, NE-SW and N-S). On the peel block and on the southern border of the RVG, the NW-SE lineaments prevail whereas the central part of the RVG is characterized by the predominance of the NE-SW orientation (Van den Berg et al., 1994). Such a fault pattern has been interpreted as the result of a present-day strike-slip motion of the RVRS where the PBZF and the FFZ play the role of the main strike slip faults (Van den Berg, 1994). Nevertheless, Houtgast et al. (2002) have recently shown that the FFZ was characterized by a normal faulting mode during the quaternary. To solve these antagonist interpretations, we analyze a high precision DEM in order to quantify the vertical and lateral displacement along the PBFZ and the FFZ.

\section{Methodology}

\subsection{DEM analysis}

Our study aims to analyze the present-day deformation of the surface along the RVG border faults (i.e., the 
PBFZ and the FFZ). Three different areas were selected taking into account the importance of the fault trace in the field, the location of several trenches dug during previous studies (Van den Berg et al., 2002; Houtgast et al., 2003) and the seismicity recorded since the beginning of the XXth century (Fig. 3). In Limburg (southern part of the Netherlands), the tectonic activity of the FFZ was intensively studied by shallow well analysis, trenching and mapping of the Meuse terraces (Van den Berg, 1989; Van Balen et al., 2000; Houtgast et al., 2002). We have also studied this zone with the DEM in order to compare our results to those obtained with different approaches. On the PBFZ we have selected the two most seismic active zones, which are the Uden area in the northwestern part of the RVG and the Roermond area in the south-east, as demonstrated by the occurrence of two large earthquakes during the XXth century: the Roermond earthquake $\left(M_{1}=5.8\right)$ in 1992 and the Uden earthquake $\left(M_{1}=5.5\right)$ in 1932.

The data on which the DEMs are based were obtained by laser altimetry (Rijkswaterstaat, 2000). The original data density is at least one data point per $16 \mathrm{~m}^{2}$, with the exception of heavily forested areas where the density is half. The original data have been partly corrected for outliers, vegetation and buildings, except for urbanized areas. As the filtering has been made by different private companies, the quality of the data may vary. The DEM is constructed from the filtered data by interpolation to a $5 \mathrm{~m} \times 5 \mathrm{~m}$ grid by inverse-squared distance weighting, with a footprint of $8 \mathrm{~m}$. By comparison of the laser altimetry-derived data to reference points the precision in the horizontal plane is calculated to be less than
$30 \mathrm{~cm}$. For the $5 \mathrm{~m} \times 5 \mathrm{~m}$ DEM the standard error in the estimated heights is $16 \mathrm{~cm}(68 \%$ of the data has an error less than $16 \mathrm{~cm}$ ).

In the different areas, the surface deformation was measured from the DEM. For each fault, we determined several parallel topographic profiles distributed perpendicular to the fault trace. The location of each profile was selected by taking into account the influence of human activity, vegetation and erosion and sedimentation, and the offset values were corrected for these parameters. Because a fault scarp is continuously smoothed by erosion, the length of our profiles taken is large enough (between 600 and $4000 \mathrm{~m}$; average length around $1200 \mathrm{~m}$ ) to prevent this problem. The offset value is determined from the difference between the average elevations of the footwall and the hangingwall (Fig 4). The comparison of offset values determined from the DEM with those obtained from shallow well analysis (Houtgast et al., 2002) and trenching (Van den Berg et al., 2002; Houtgast et al., this issue) reveals nearly similar results, which allows a validation of our method.

We use two types of stable geological markers to determine the fault motion along the FFZ and the PBFZ: eolian dunes and Paleo-Meuse terrace boundaries. The eolian dunes and the fluvial terraces are mainly composed of sand, which is a material that well records passively vertical and horizontal deformations as shown in analogue experiments (e.g., Davy and Cobbold, 1991). Deformation was studied with young (eolian dunes $-11.5 \mathrm{ky}-$ ) and old (paleo-Meuse terraces-several $100 \mathrm{ky}$ ) formations in order to cover a larger time scale.

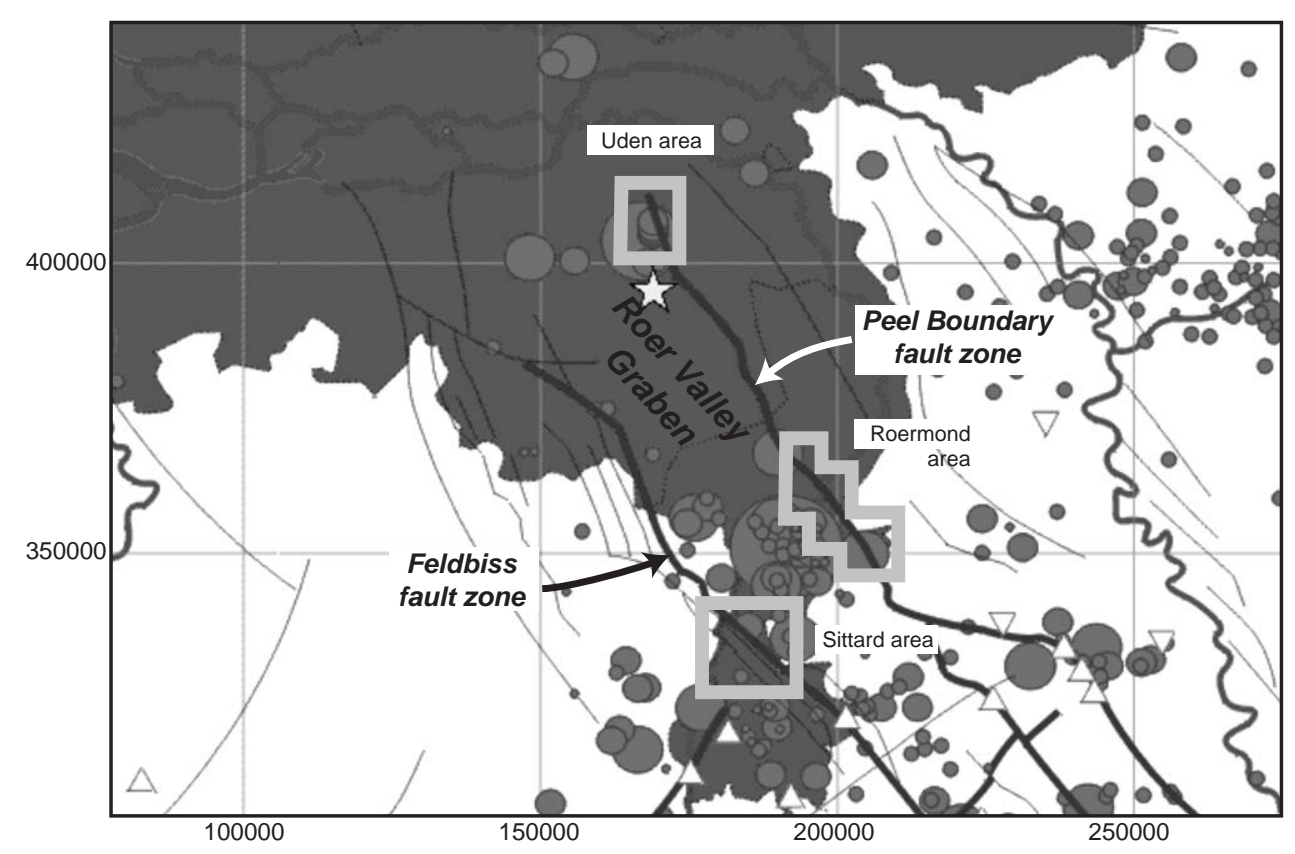

Fig. 3. Location of the three areas covered by the $5 \mathrm{~m}$ step digital elevation models. The background map corresponds to the distribution of the recent seismicity recorded by Dutch Seismological Institute (KNMI). 

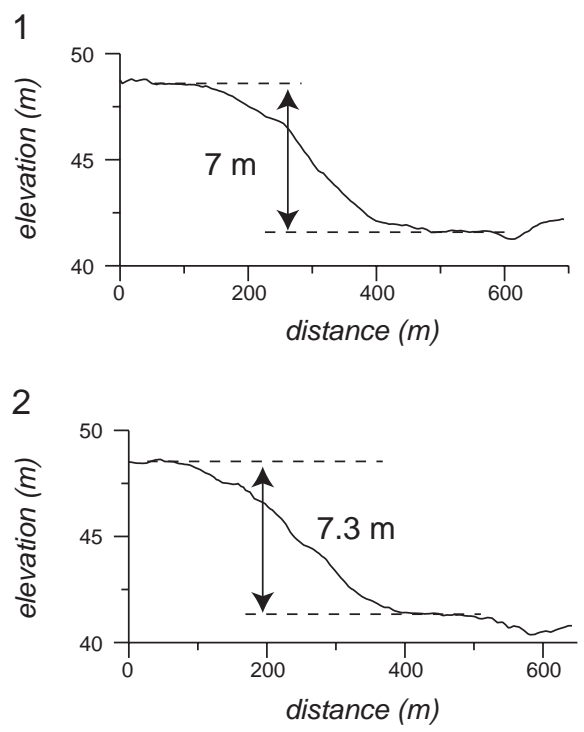
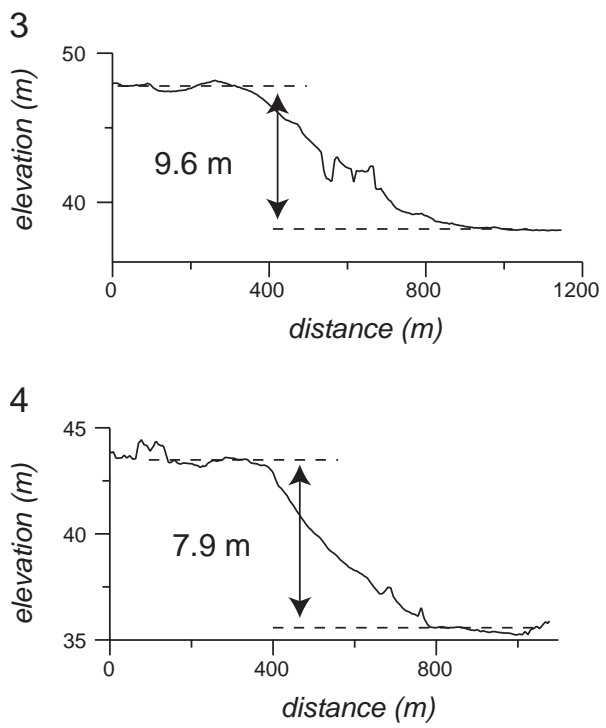

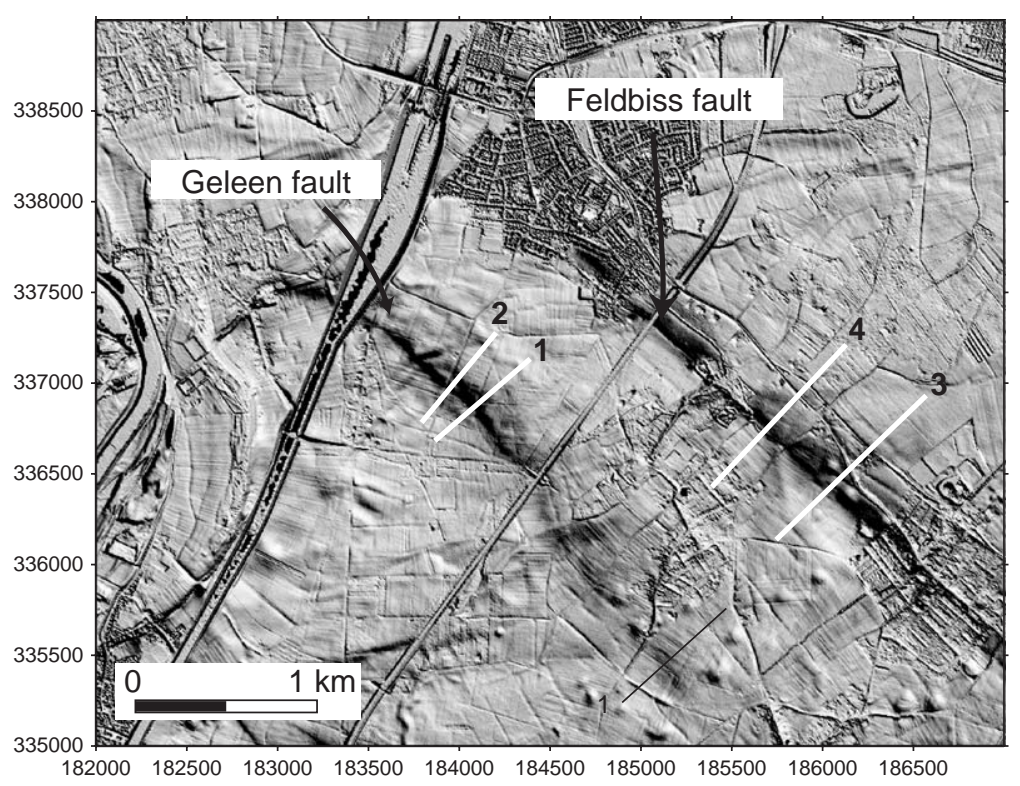

Fig. 4. Example of several SW-NE trending topographic profiles used to determine the offset between the foot-wall and the hanging-wall on both sides of the FFZ. Offsets created by the PBFZ activity were determined with the same methodology.

\subsection{Age of the formations}

The geomorphological and sedimentological evolution during the most recent geological history (Saalian to Holocene) of the southeastern part of the Netherlands is important to date the fault movements, and, to some extent, to interpret the fault scarps. Terraces formed by the Meuse river characterize the landscapes near Sittard and Roermond. These terraces are well dated, especially the younger ones, which are used in our work. The terrace sequence is a consequence of the long-term uplift of the area (Van den Berg, 1989; Van Balen et al., 2000), but they are also faulted. The displacement of the terraces can be used to determine fault displacement rates and fault pattern (Houtgast et al., 2002). Periglacial eolian processes have deposited a blanket of fine sand and loess everywhere in the study area during the Weichselian Pleniglacial, except on the Lateglacial to Holocene terraces near the Meuse. This blanket has probably leveled the fault-related morphology of pre-Weichselian age. During the late Pleniglacial and the Lateglacial, dunes were formed in the Uden and Roermond areas. In the Sittard area, the eolian deposits are too fine grained (loess) for dune formation. Near Roermond these dunes are faulted. More detailed information on the geomorphology and sedimentology will be given in the discussion of different areas. 


\section{Results}

\subsection{Geometry of the active faults}

The DEM analysis reveals surface escarpments along the graben border faults, which are not single faults but correspond to active fault zones composed of parallel faults.

In the Sittard area (Fig. 5), the Geleen and Feldbiss faults were already recognized as forming an overstepping fault system (Houtgast et al., 2002). The shaded relief image indicates that the Geleen fault corresponds to several adjacent and kilometric-long segments of faults whereas the Feldbiss fault is a unique and linear fault (Fig. 5). As indicated by well analysis (Houtgast et al., 2002), the Geleen fault progressively disappears toward the South-East where its displacement is taken over by the Feldbiss fault. The DEM also allows the determination of the surface deformation generated by the Heerlerheide fault zone in the Late Saalian deposits (i.e., $130 \mathrm{ka}$ ). This fault zone is bounded in the South and the North by two main normal faults of which the southern limit corresponds to the main fault visible in seismic cross-sections. Between these two faults, the differential deformation is accommodated by a $150-200 \mathrm{~m}$ wide micro-graben. It is worth noting that the complex geometry of the Heerlerheide fault zone is directly controlled by a Carboniferous fault system, which consists in this area of two parallel faults coincident with the limit of the present-day deformed area. In the northwestern part of the study area, the recent activity of the FFZ cannot be recognized in the young Meuse terraces ( 3 and $11 \mathrm{ka}$ ). According to the displacement rates determined by Houtgast et al. (2002) for the Feldbiss and Geleen faults ( 24 and $28 \mathrm{~mm} /$ ky, respectively), the surface displacements associated with the Feldbiss and Geleen faults are about $0.3 \mathrm{~m}$ in the Geistingen terrace $(11 \mathrm{ka})$. The anthropogenic activity, the orientation of the Paleo-Meuse meanders and the standard error of the DEM probably not allow the detection of such small surface deformations linked to fault activity. The fault orientation inferred from the DEM indicates a very constant trend around N130-140 for the FFZ (Fig. 6a).

In the Roermond area, the surface deformation generated by the PBFZ activity is visible along a $20 \mathrm{~km}$-long segment (Fig. 7). Contrary to the FFZ in the Sittard area, the PBFZ corresponds here to a unique fault with a clear trace on the DEM except between Neer and Roermond where the Meuse River crosscuts the PBFZ. This trace has different orientations depending on the area. In the southern part, the PBFZ presents
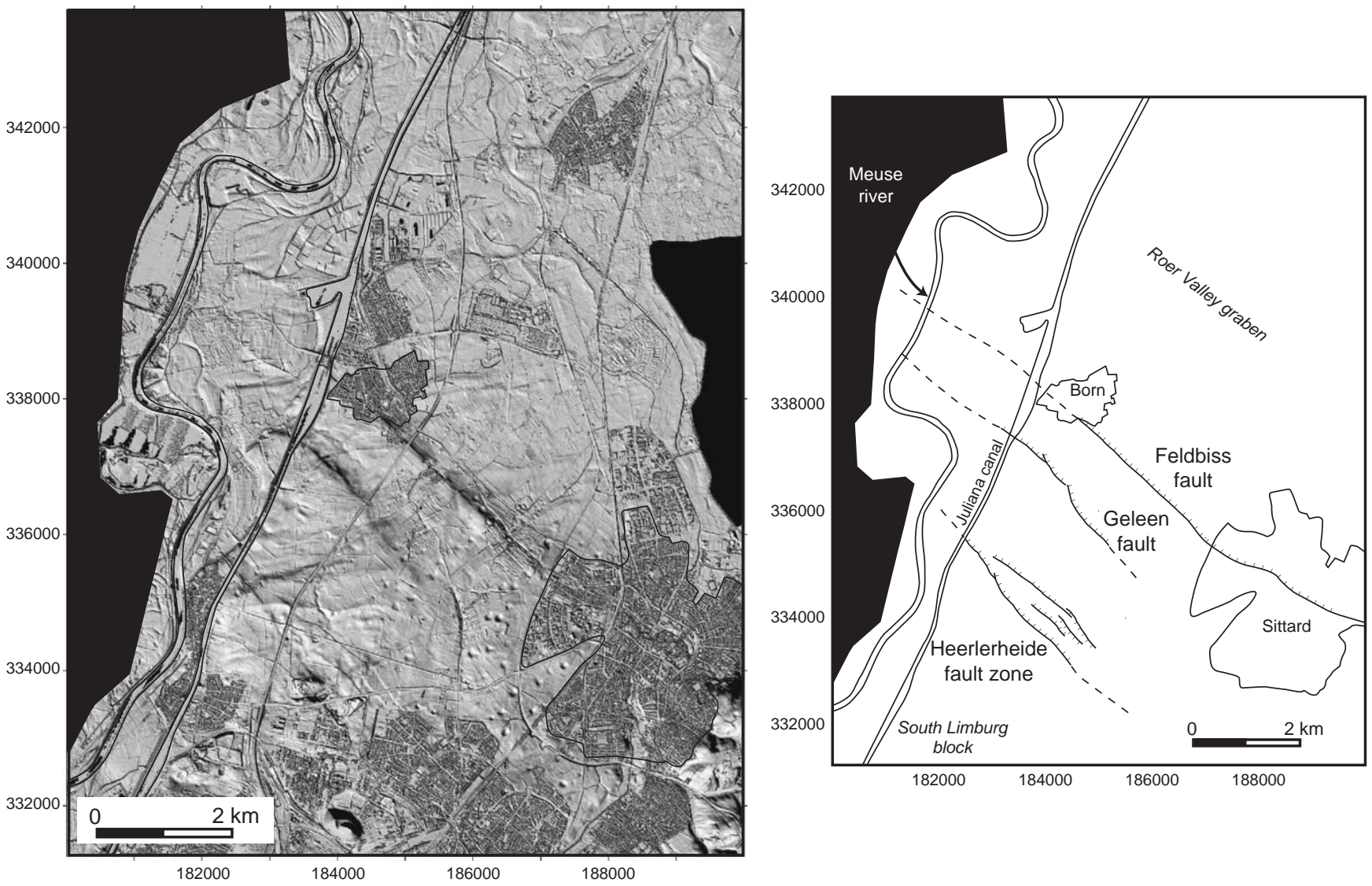

Fig. 5. Geometry of the FFZ in the Sittard area. The shaded relief map is characterized by an artificial illumination from the SW. NW-SE lineaments corresponds to the FFZ trace while SW-NE lineaments results from paleo-Meuse terrace boundaries as revealed by Houtgast et al., 2002. 
Sittard area

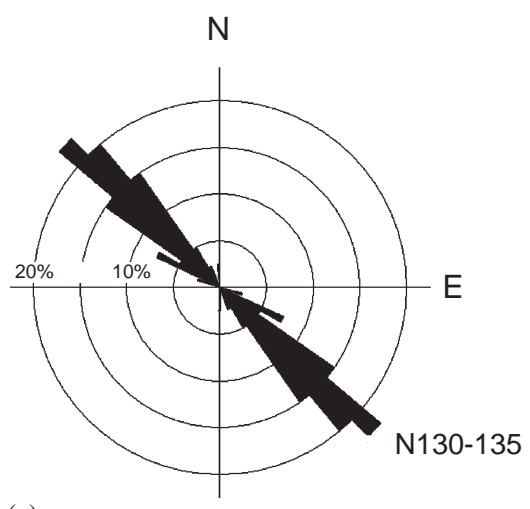

(a)
Roermond area

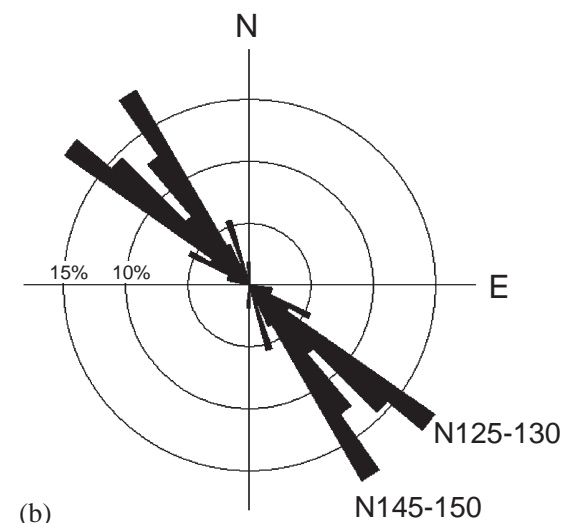

Uden area

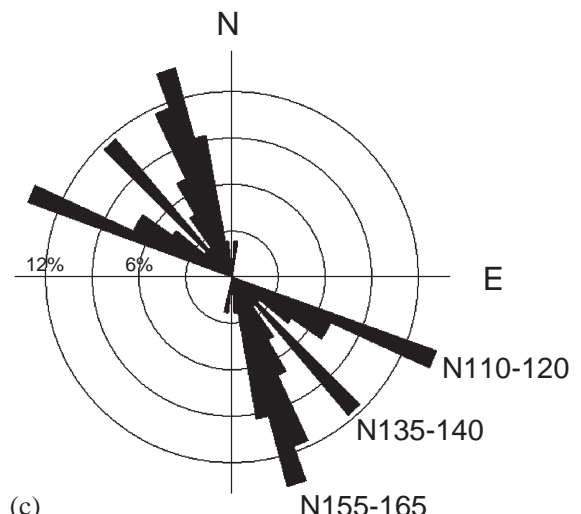

(c)

Fig. 6. Rose diagrams showing the direction of the active faults in (a) the Sittard area, (b) the Roermond area and (c) the Uden area.

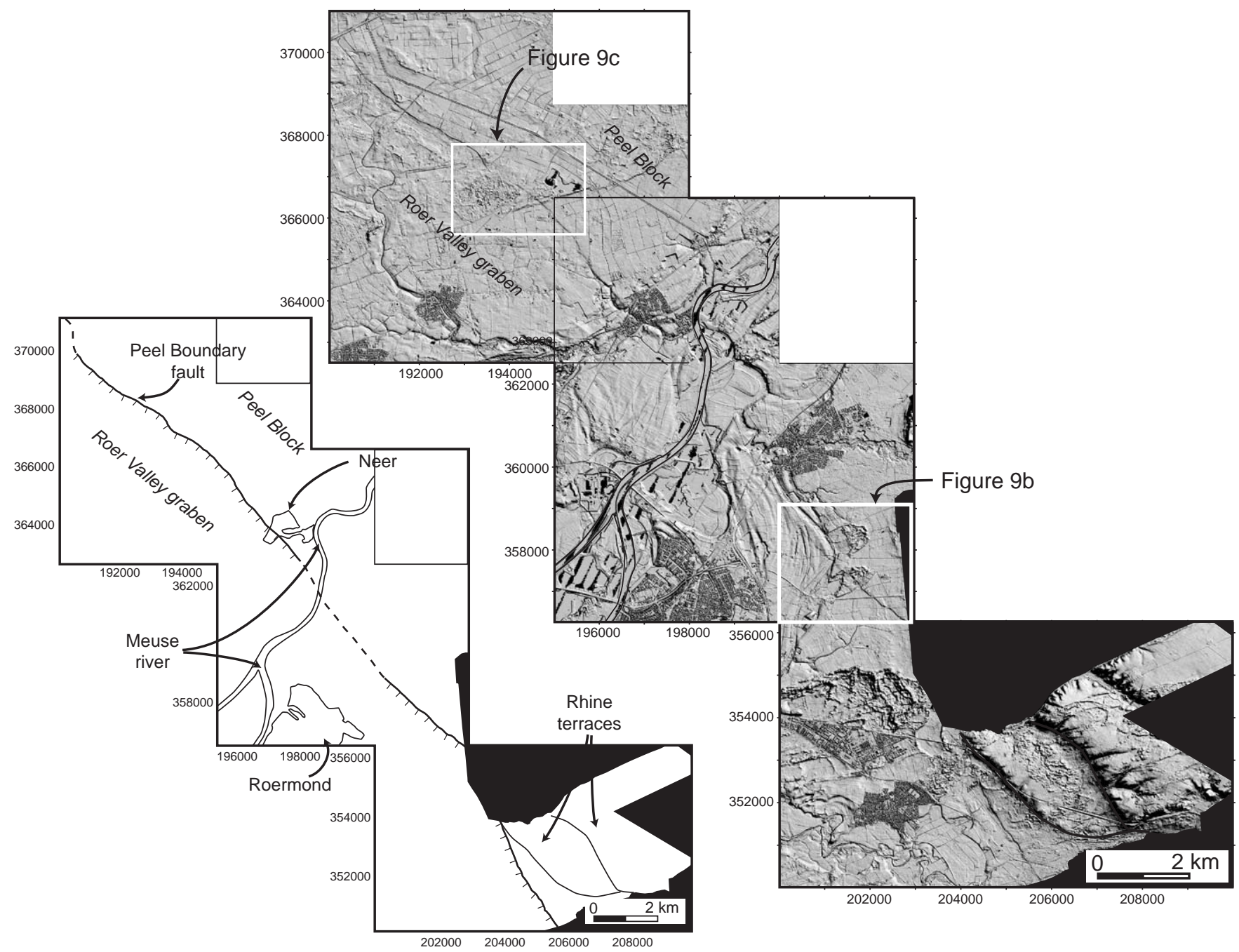

Fig. 7. Geometry of the southern segment of the PBFZ in the Roermond area. The shaded relief map is characterized by an artificial illumination from the NE.

a N145-150 average orientation. The second main orientation (N125-130) is represented east of Roermond and in the northwestern part of the studied area. Thus, the general NW-SE orientation of the PBFZ results in the Roermond area from the combination of two main fault trends (N125-130 and N145-150) (Fig. 6b). 
In the northwestern part of the RVRS, the PBFZ geometry is more complex with the development of two $\sim 14 \mathrm{~km}$-long parallel faults: the peel boundary fault in the West and the 2nd peel boundary fault in the east (Fig. 8). From the south-east, these faults present long and linear traces that are from south to north westward shifted by two N110-120 fault segments of about $2 \mathrm{~km}$. In the north, the scarp of the 2 nd peel boundary progressively dies out whereas the deformation due to the peel boundary fault is still visible in the northwestern corner of the study area (Fig. 8). In the southern part of the studied area, the peel boundary fault scarp decreases south of Uden. Nevertheless, combination of the elevation map and the shaded relief image indicates that the fault continues with smaller offsets. Analysis of the fault orientation reveals the occurrence of three directions of faults: N110-120, N135-140 and N155-160 (Fig. 6c). The first trend (i.e., N110-120) corresponds to the direction of the oblique faults, which control the lateral shift of the peel boundary fault and the 2 nd peel boundary fault north of Uden. The two other directions represent the local changes of the PBFZ orientations.

\subsection{Characterization of fault motion}

Using passive geological markers such as stable eolian dunes and Paleo-Meuse terrace boundaries, we determined precisely the fault motion along the FFZ and the

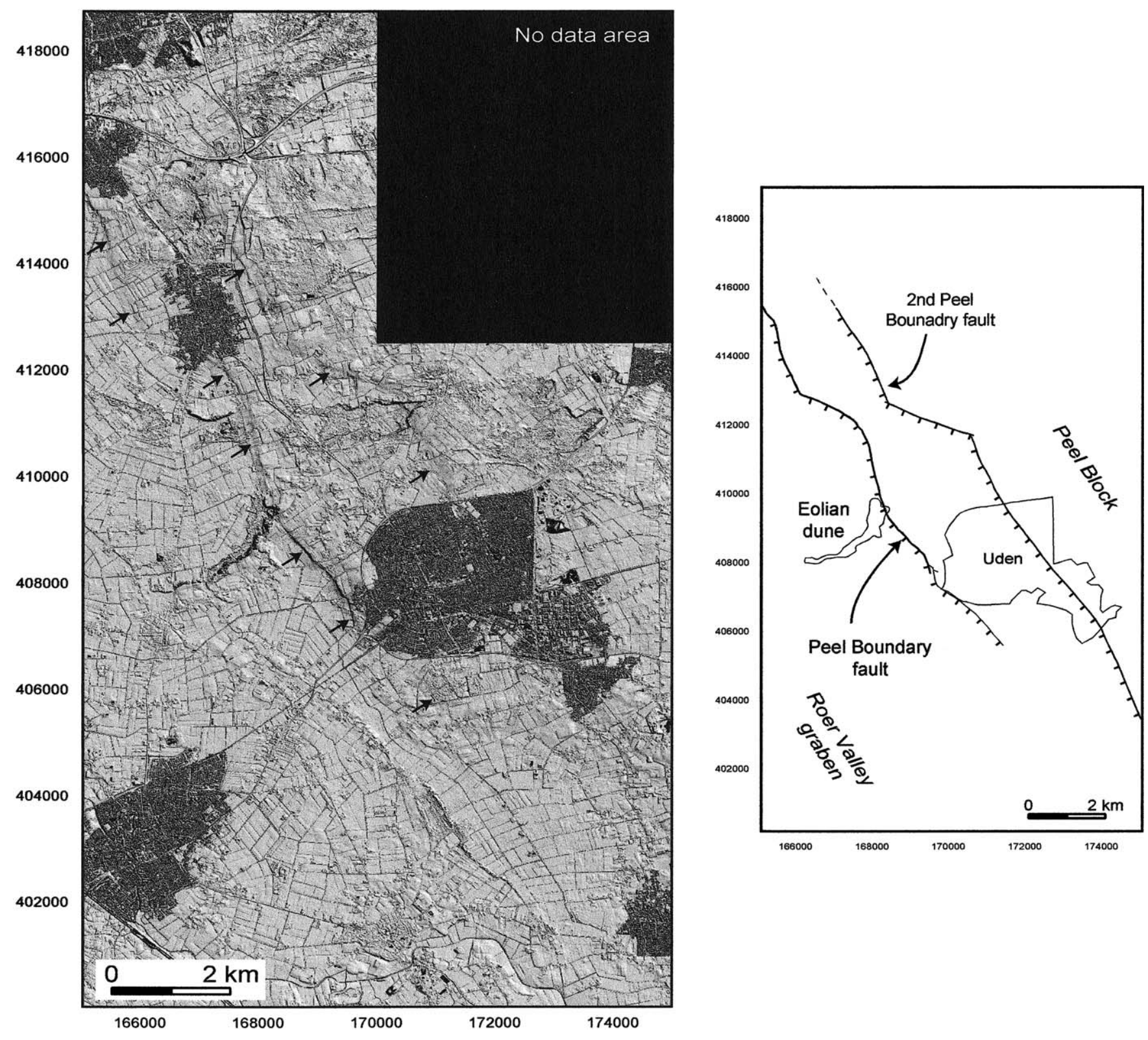

Fig. 8. Geometry of the northern segment of the PBFZ in the Uden area. The shaded relief map is characterized by an artificial illumination from the NE. Small arrows indicate the location of the escarpments associated with the fault activity. 
PBFZ. In the Sittard area, the lack of lateral offset and the important vertical deformation (i.e., up to $7.2 \mathrm{~m}$ ) of the Paleo-Meuse terrace limits where they crosscut the FFZ suggests that the faults representing this trend are pure normal faults since at least $330 \mathrm{ky}$ (i.e., age of the older Meuse terrace boundary in the studied area) (Fig. 9a). East of Roermond, the vertical displacement of recent geological formations, like eolian dunes and meander scroll bars, without any lateral component indicates that the southeastern part of the PBFZ is characterized by pure normal faulting since $12.9 \mathrm{ky}$ (i.e., age of the scroll bars) (Fig. 9b). West of Roermond, a similar fault motion is determined as the limit of the Late Pleniglacial terrace present a vertical offset of about $1 \mathrm{~m}$ with no lateral displacement (Fig. 9c). Like in the Roermond area, passive markers of the deformation (i.e., eolian dunes) in the Uden area indicate that the PBFZ is characterized by a normal faulting mode in its northwestern part (Fig. 9d).

\subsection{Quantification and age of the deformation}

The use of a high precision DEM allows determination of the escarpments associated with the fault

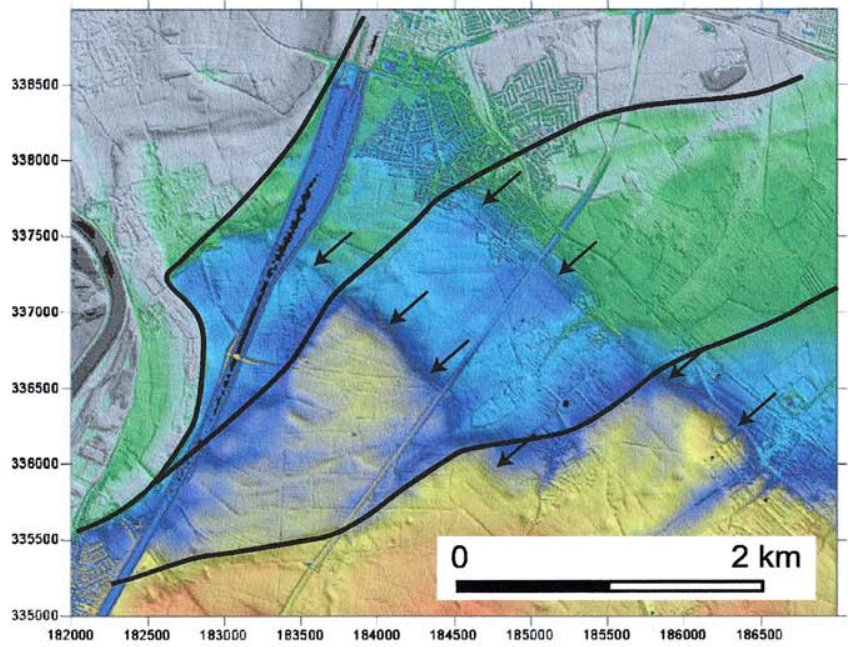

(a)

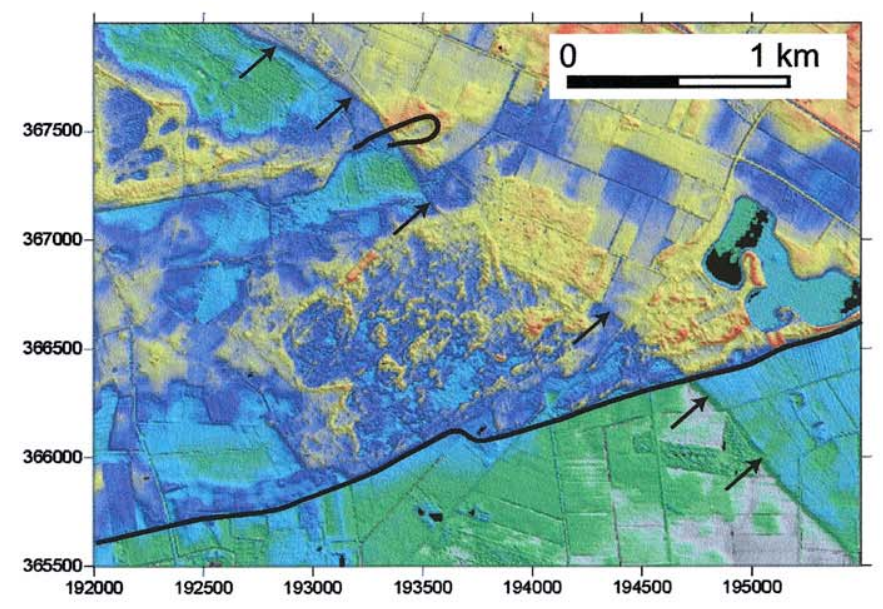

(c)

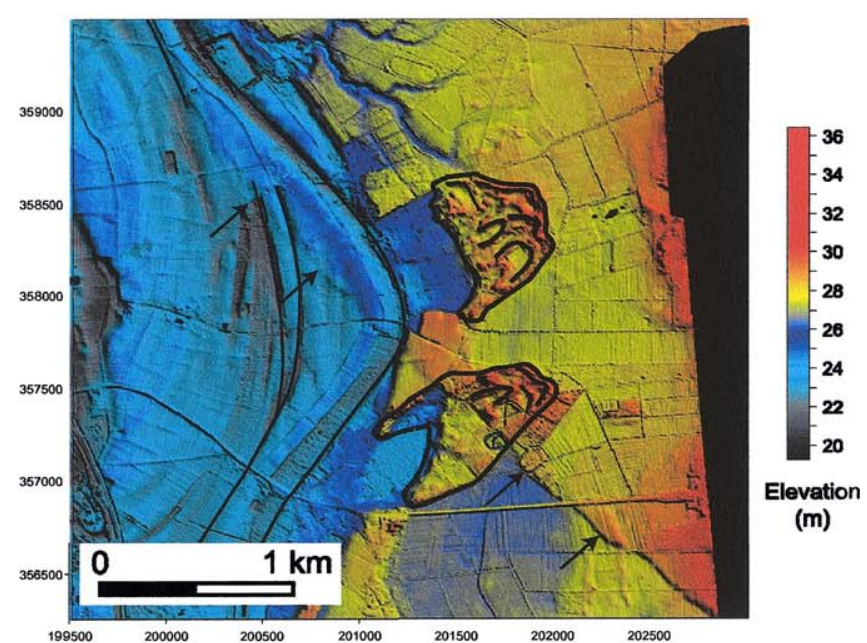

(b)

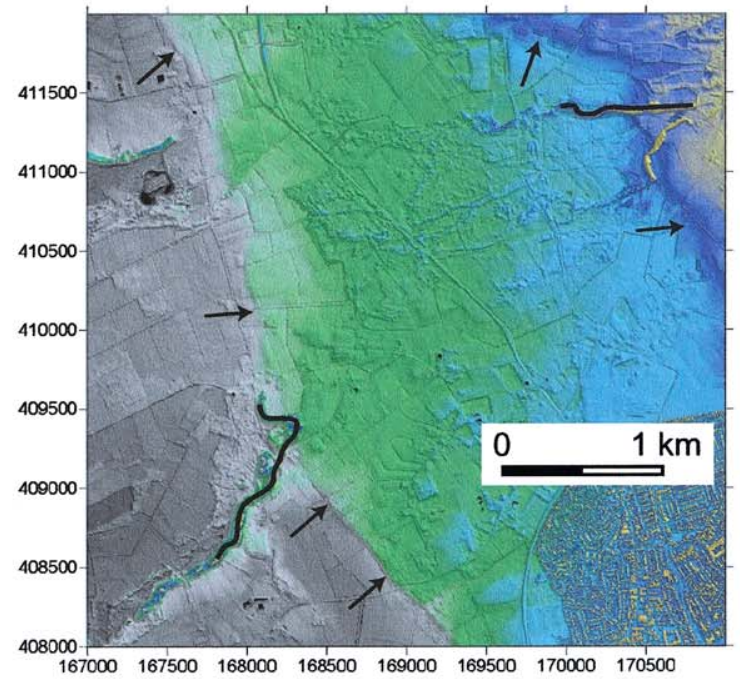

(d)

Fig. 9. Deformation of the eolian dunes and paleo-Meuse terraces induced by tectonic activity (see the black arrows for fault location). (a) In the Sittard area, the terrace boundaries (black lines) present a vertical displacement without any lateral offset. Increasing elevations are represented by black, gray, green, blue, yellow and red colors. (b) East of Roermond, the PBFZ activity deforms an eolian dune in the vertical plane only, proving the pure normal mode of deformation of the PBFZ. (c) West of Roermond, the vertical deformation of the Late Pleniglacial terrace limit and the eolian dunes confirms this fault motion for the southeastern part of the PBFZ (same color scale than A). (d) In the Uden area, the PBFZ, which is composed by two parallel faults offsets the eolian dunes only vertically proving that the PBFZ is a pure normal fault (same color scale than A). 
activity. Knowing the age of the Paleo-Meuse terraces upper part (i.e., when the river abandoned the terrace) and the age of eolian dune formation, which are affected by the tectonic activity, we have deduced displacement rates along the FFZ and the PBFZ.

\subsubsection{Sittard area}

In this part of the RVRS, the FFZ is crossed by the Meuse river. Uplift of the area South of the FFZ caused the Meuse river to incise during the Pliocene and the Quaternary, and as a consequence, a flight of terraces was formed (e.g. Van den Berg, 1989; Van Balen et al., 2000; Houtgast et al., 2002). The terrace deposits are often covered by eolian deposits, mainly sandy loess (Mücher, 1986). The terrace deposits are underlain by tertiary Breda or Kiezelöoliet formations, which consist of fine to coarse sands (Felder et al., 1989). Due to northwestward tilting, terrace remnants are preserved mainly on the east bank of the Meuse river valley. The Meuse terraces in South Limburg have been the subject of many studies and have been extensively described (for an overview see Houtgast et al., 2002). Five terrace levels can be discriminated in the study area.

The oldest terrace in the study area is the Caberg-1 terrace (Fig. 10a). By interpolation and by correlation to the $\delta^{18} \mathrm{O}$ curve of ODP 667 the age of this terrace is estimated at $420 \mathrm{ka}$ (Van den Berg, 1989; Houtgast et al., 2002). Similarly, the next younger terrace, Caberg-2, is estimated at $330 \mathrm{ka}$. The Caberg-3 terrace is dated by thermoluminescence and paleontological remains at $250 \pm 20 \mathrm{ka}$ (Huxtable and Aitken, 1985; Van Kolfschoten et al., 1993). By correlation to the $\delta^{18} \mathrm{O}$ curve of ODP 667, the Eisden-Lanklaar terrace is estimated to be $130 \mathrm{ka}$ (Van den Berg, 1989; Houtgast et al., 2002). An important stratigraphic characteristic of the next younger terrace, the Geistingen terrace, is the complete absence of eolian coversands. Consequently, this terrace was formed during or after the last period of coversand deposition, i.e. during or after the Younger Dryas period (Paulissen, 1973), estimated at 11.5 cal (calibrated) $\mathrm{ka} \mathrm{BP}\left(10 \mathrm{ka}^{14} \mathrm{C}\right)$.

In the Sittard area, 14 topographic profiles perpendicular to the Geleen and Feldbiss faults are used to determine the offsets related to fault displacements (Fig. 10a). On the Geleen fault, the escarpment reaches a maximum value of $7.4 \mathrm{~m}$ in the central part of the fault (i.e., on the Caberg-3 terrace). From this location, the surface deformation decreases progressively toward the south-east and abruptly toward the north-west down to $4.1 \mathrm{~m}$ (Fig. 10a). In more detail, the surface deformation created by the fault activity for each terrace is maximum in its northwestern part and decreases progressively toward the south-east. The deformation along the Feldbiss fault has been determined from 7 topographic profiles distributed on terraces dating between 130 and
$420 \mathrm{ky}$. These profiles show (1) a general step-like increase of the offsets from the youngest to oldest terraces and (2) a slight increase of the surface deformation toward the south-east for each terrace (Fig. 10b). Topographic profiles CSF7 and CSF8 show again an increase of the displacement linked to the Feldbiss fault. However, in this part of the Sittard area, the surface of the Caberg-1 terrace is covered by a thick loess deposit, forming a ridge (see Fig. 8 in Houtgast et al., 2002). The surface topography then corresponds to the accumulation of the deformation associated to the Feldbiss fault activity and the preexisting topography of the Caberg-1 terrace.

Considering the offsets determined from the DEM analysis and the age of the Paleo-Meuse terraces, we calculated displacement rates along the Geleen and the Feldbiss faults (Fig. 10b). As previously demonstrated by analyses of borehole data by Houtgast et al. (2002), the displacement rate along the Geleen fault decreases toward the south-east. In the northwestern end of the visible Geleen fault, the displacement rate is around $33 \mathrm{~mm} / \mathrm{ky}$ and it decreases progressively down to $14.5 \mathrm{~mm} / \mathrm{ky}$ in its south-eastern extremity. It is important to note that the values obtained from the offset at the base of the terrace (Houtgast et al., 2002) and from the surface deformation are nearly similar. Consequently, the deformation observed at the surface mainly results from tectonic activity and was hardly affected by differential erosion and sedimentation between the footwall and the hangingwall. Contrary to the Geleen fault, the Feldbiss fault presents an increase of the displacement rate toward the south-east. On the Eisden-Lanklaar terrace, the displacement rate inferred from the offset of $3.8 \mathrm{~m}$ is $29.2 \mathrm{~mm} / \mathrm{ky}$. The rate progressively increases up to $39 \mathrm{~mm} / \mathrm{ky}$ determined for a displacement of $12.9 \mathrm{~m}$ affecting the Caberg-2 terrace. The offset values deduced for topographic profiles CSF7 and CSF8 being partly wrong (see discussion in the previous paragraph), we do not incorporate the displacement rates for these profiles in our study. Although the general tendency observed for the variation of the displacement rate along the Feldbiss fault is similar for the present study and that of Houtgast et al. (2002), the exact values of the displacement rates are different: Eisden-Lanklaar $19 \mathrm{~mm} / \mathrm{ky}$, Caberg-3 $26 \mathrm{~mm} / \mathrm{ky}$ and Caberg-2 $31 \mathrm{~mm} /$ ky. However, results of a recent study of a trench across the Feldbiss fault showed that the offset value at the Caberg-3 terrace obtained by Houtgast et al. (2002) from an analyses of borehole data were underestimated by about $50 \%$ ( $10 \mathrm{~m}$ instead of $6 \mathrm{~m}$; Houtgast et al., this issue).

\subsubsection{Roermond area}

In this study area the Meuse river crosses the PBFZ. During the late Saalian to Holocene time interval the 

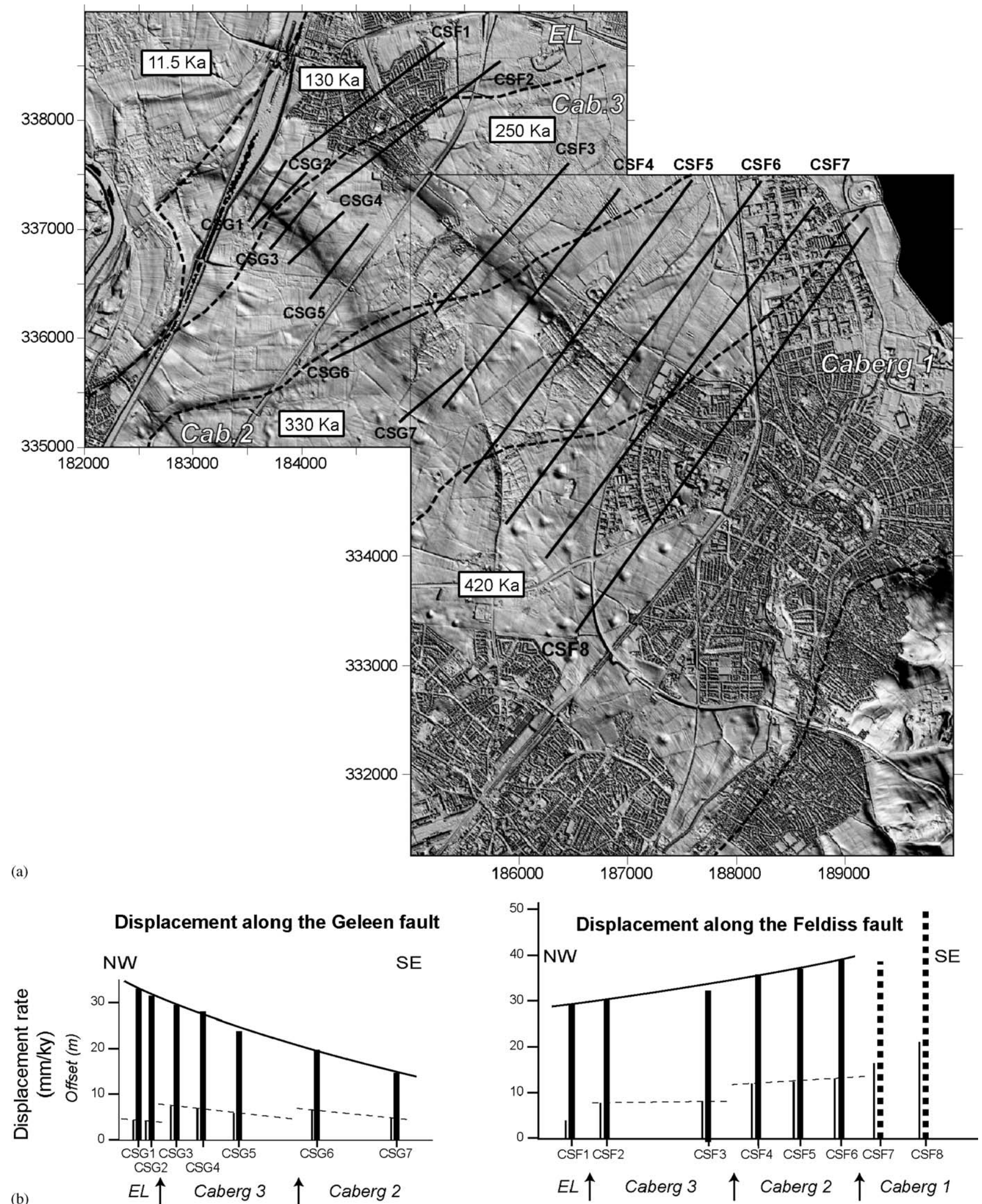

Fig. 10. (a) Location and age of the paleo-Meuse terraces in the Sittard area (after Houtgast et al., 2002). Dashed lines represent the limits of the paleo-Meuse terraces. The topographic profiles used in the present study are represented by black linear segment named CSG for the Geleen fault and CSF for the Feldbiss fault. (b) Evolution of the escarpment (thin lines) and the displacement rate (thick lines) along the Geleen and Feldbiss faults. The same vertical scale and different units are used for the displacement rates and the offset. Profiles CSF7 and CSF8 (thick dashed lines) are not integrated in the study as the escarpment is disturbed by the development of a valley and by an important loess deposit. 
Meuse river formed an incised valley in this study area (Zonneveld, 1974; Van den Berg, 1989) with terraces which can be correlated southward to the Sittard area (see above) and northward, across the peel block, to the border of the Rhine-Meuse delta (Zonneveld, 1974; Huisink, 2000). The terraces are covered by eolian sandsheet deposits. The most characteristic terrace in the study area has a ridge and swale morphology, which was formed by a meandering river (Paleo Meuse). Similar river terrace fragments have been documented further downstream (e.g. Huisink, 2000), and dated at an Allerød age (12.9 cal ka BP, $\left.11.0{ }^{14} \mathrm{C} \mathrm{ka}\right)$. The next lower terrace is characterized by a relatively straight, braided river channel pattern. This terrace is also documented further downstream and dated at a Younger Dryas age $\left(11.5 \mathrm{cal} \mathrm{ka} \mathrm{BP}, 10.0{ }^{14} \mathrm{C} \mathrm{ka}\right)$. The terrace gradients resulting from the downstream correlation are in line with the present-day river gradient, confirming the correlations. On the south-eastern side of the Meuse valley, the Allerød terrace is cut in to an older terrace of either Pleniglacial (Zuidam, 1980) or late Saalian (Zonneveld, 1974) age (Fig. 11a). A late Saalian interpretation is supported by the vertical position of a river terrace on the other side of the Meuse valley, to the

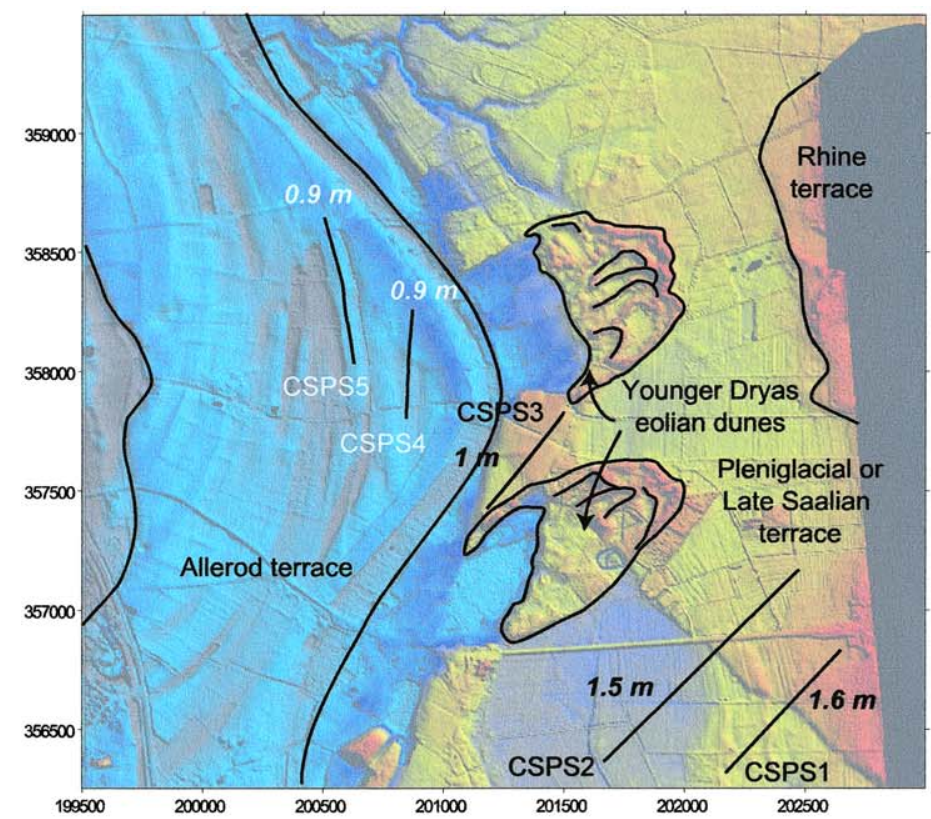

(a)

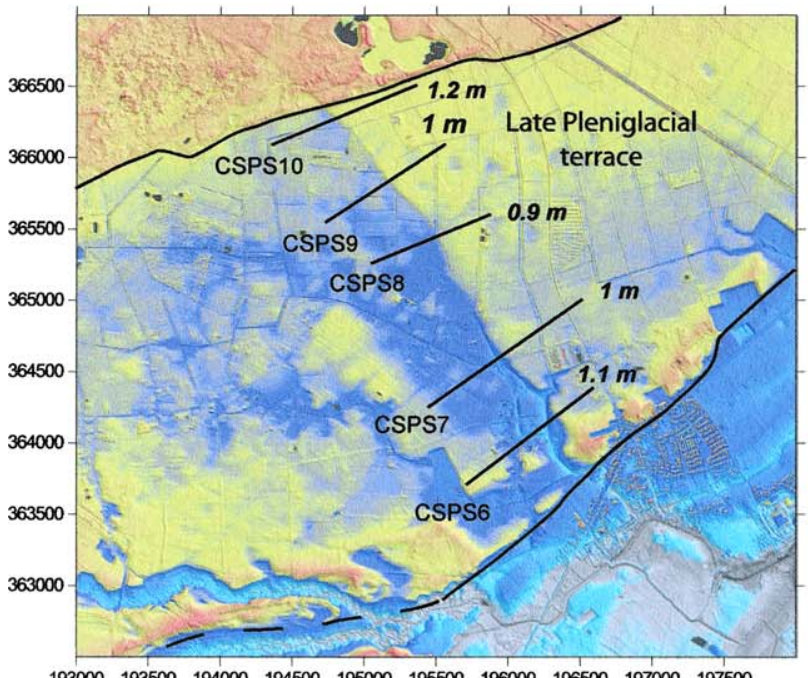

b)

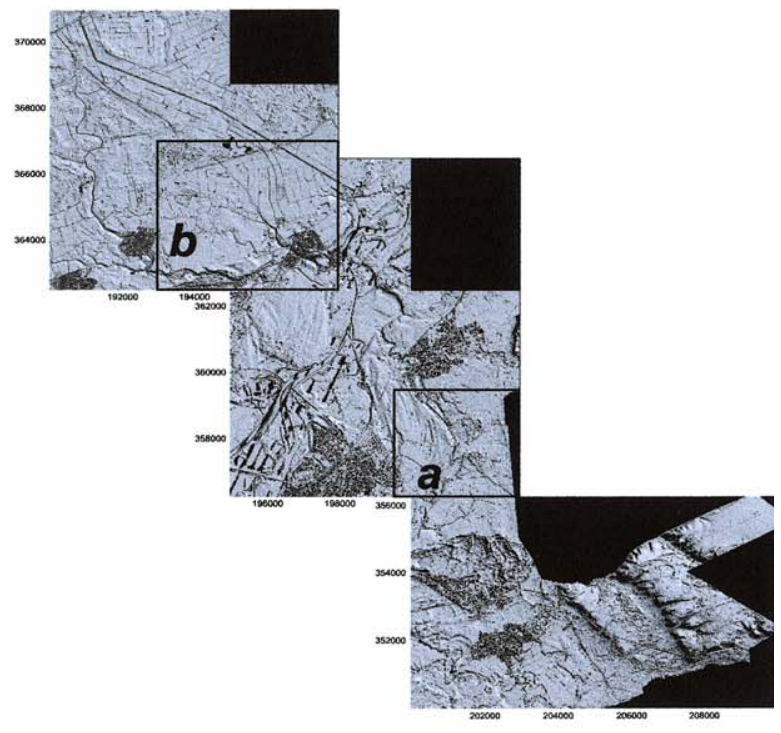

Fig. 11. Age and deformation of the Quaternary formations used in the Roermond area for the determination of the displacement rates on the eastern (a) and western (b) sides of the Meuse river valley. For each topographic profile the name and the offset value are indicated. Gray and blue colors and yellow and red colors correspond to low and high elevation, respectively. 
west of Roermond (Fig. 11b), which is of Pleniglacial age according to Van den Berg et al. (2002). This terrace is in a morphological lower position than the terrace level under consideration, but higher than the Allerød level. A Pleniglacial age, on the other hand, is consistent with the local geology. Eolian dunes of Younger Dryas age are located on top of the terrace (Fig. 11a). The dunes are displaced by the PBFZ. Drilling into the dunes revealed that floodplain loam deposits are preserved in between the base of the dune and the eolian top of the underlying terrace, with an equal thickness on both sides of the fault. Given their distance of less than $200 \mathrm{~m}$ to the Allerød channel and their stratigraphic position, the most likely age for these loams is Allerød. This interpretation favors a Pleniglacial age of the terrace deposits underlying the loam. In any case, the late Pleniglacial sand sheet deposits on top of the terrace will have partly or completely leveled the fault scarp morphology, which is confirmed by the similar thickness of the loam (post-dating the eolian sand sheets) on both sides of the fault.

Analysis of the fault segment located on both sides of the Meuse river allows determination of the offsets induced by a fault activity (Fig. 11). East of Roermond (i.e., on the eastern side of the Meuse river valley), the offsets determined from the topographic profiles CSPS4, CSPS5 and CSPS6 at the top of the Allerød terrace vary between 0.7 and $1 \mathrm{~m}$ (average value of $0.85 \mathrm{~m}$ ) (Fig. 11a). Considering the age of the terrace, this suggests an average displacement rate of $66 \mathrm{~mm} / \mathrm{ky}$. East of the Allerød terrace, the offsets range between $1 \mathrm{~m}$ (CSPS3) and $1.6 \mathrm{~m}$ (CSPS1) at the top of the Late Saalian or Pleniglacial terrace. The high values deduced South-East of the eolian dune can result either from a larger tectonic activity in the southeastern part of the study area or from a remnant offset which was not completely leveled during the emplacement of the sandsheet. Assuming that the sandsheet, covering the terrace dates from the late Pleniglacial, we obtain displacement rates ranging from 69 to $111 \mathrm{~mm} / \mathrm{ky}$. Finally, the Younger Dryas eolian dune affected by the fault activity has an offset of $0.9 \mathrm{~m}$ at its base and $0.8 \mathrm{~m}$ at the top (offset estimated from the envelope curve), which indicates a displacement rate of $70 \mathrm{~mm} / \mathrm{ky}$. On the western side of the Meuse river valley, the offsets inferred from the topographic profiles at the top ofthe Pleniglacial terrace vary between 0.9 and $1.2 \mathrm{~m}$ (Fig. 11b). A similar value $(0.9-1 \mathrm{~m})$ was observed in a trench dug at the same location as the topographic profile CSPS7 (Van den Berg et al., 2002). According to our values, the average displacement rate is around $65 \mathrm{~mm} / \mathrm{ky}$ for this segment of the PBFZ; the high displacement rates obtained from the topographic profiles CSPS1 and CSPS2 do not represent a larger tectonic activity but probably results from a remnant offset before the deposition of the sandsheet.

\subsubsection{Uden area}

Tectonically, the Uden area is situated at the northeastern rim of the RVRS. The Roer valley graben is situated to the southwest of the fault scarps, the peel block is to the northeast. As a result, the subsurface geological build-up is quite different in terms of the completeness and thickness of the Cenozoic deposits (Van den Toorn, 1967; Bisschops, 1973; Van Balen et al., 2000). During the early Pleistocene the RVG was a depocentre for the Meuse as well as the Rhine river. However, during the early Middle Pleistocene the Rhine took abruptly a more northward directed course, whereas the Meuse changed its course gradually northwards, leaving deposits on the peel block. After the Meuse left the area, local fluvial and eolian deposits were formed. Thus, the shallow geology of this area consists of middle Pleistocene Meuse deposits (Veghel formation; younging in a northeastward direction) overlain by eolian and local fluvial deposits of late Pleistocene age (Elsterian up to Weichselian in age), which in turn is locally overlain by Holocene peat. The largest landform in the Uden area is a wide flat area of late Pleniglacial sand sheet deposits, which formed in response to permafrost degradation (Rijks Geologische Dienst, 1983). The age of these sheet deposits is 16-14.4 cal ka BP $\left(14-12.5{ }^{14} \mathrm{C} \mathrm{Ka}\right.$; Kasse, 1999). On this planation surface eolian ridges (ER) and eolian dunes (ED) of late Bølling to Younger Dryas/early Holocene age (14.4-10.5 cal ka BP; $12.5-9.0{ }^{14} \mathrm{C}$ ka; Kasse, 1997; 1999) were formed by remobilization of the sand (Fig. 12). The dunes and ridges were reactivated during the middle ages as a result of farming activities. Some of them are still active at present, as evidenced by a lack of soil on top of them. The uplifted peel block is dissected by gullies (Fig. 12). The formation of the gullies is related to permafrost conditions, inducing enhanced surface runoff and, as a result, overdeepened fluvial valleys. They are, in origin, slightly older than the late Pleniglacial sand sheet deposits. Remnants of a small river valley are present West of the city of Uden. The valley has enhanced the size of the escarpment by fluvial incision into the late Pleniglacial eolian planation surface along the fault trace. The former river course was blocked by the formation of the dunes (ED) and ridges (ER); the river now takes a more westward course. Therefore the age of the valley is also late Pleniglacial. In the northeastern corner of the study area a small patch of the late Pleniglacial terrace (LPG) of the Meuse river is indicated (Fig. 12).

The PBFZ is represented by two parallel faults, which have induced the formation of parallel fault scarps (Figs. 8 and 12). Although the offset located at the fault escarpment can be easily determined, the amount of displacement due to tectonic activity is hard to assess. The human activity and the fluvial erosion along the scarp have potentially disturbed the original fault scarp. 


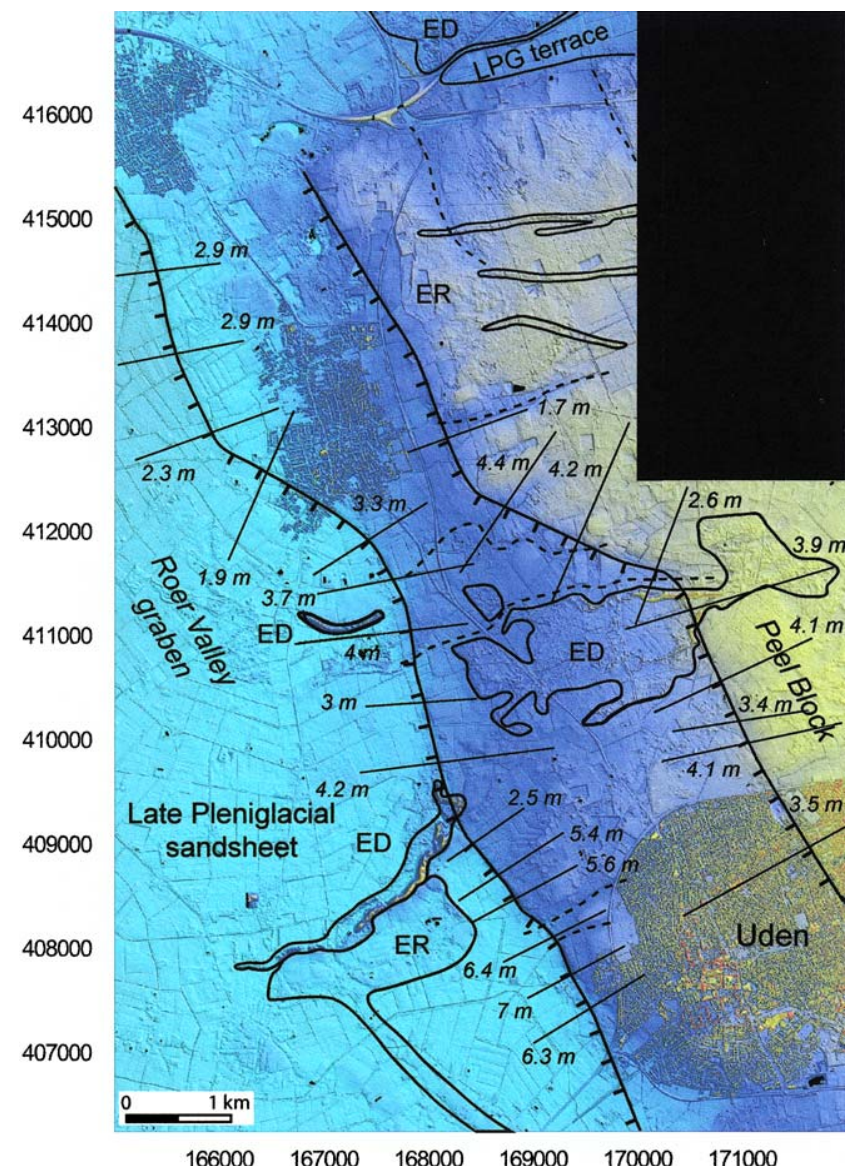

Fig. 12. Age and deformation of the Quaternary formations along peel boundary fault and the 2 nd peel boundary fault in the Uden area. Blue and yellow colors correspond to low and high elevation, respectively.

For the peel boundary fault, the topographic offsets range between 1.9 and $7 \mathrm{~m}$, with the lowest values in the northern part of the fault and the highest values West of Uden (Fig. 12). Given the occurrence of fluvial erosion and the development of gullies in the southern segment of the peel boundary fault, we consider that the offset values are not constrained enough to determine displacement rates. In contrast, the northern segment (i.e., North to the last gully) was preserved from important erosion, and the offsets (between 1.9 and $3.3 \mathrm{~m}$ ) are most likely related to fault activity. In this part, the displacement rates range between 132 and $229 \mathrm{~mm} / \mathrm{ky}$ with an average value around $184 \mathrm{~mm} / \mathrm{ky}$.

The offsets determined along the 2 nd peel boundary fault vary between 1.7 and $4.4 \mathrm{~m}$ (Fig. 12). Two of the nine topographic profiles give peculiar offset values. In the northern part, the location of the northern topographic profile in a gully can explain the relatively small offset $(1.7 \mathrm{~m}$; leveled by erosion). In the central part, the second offset value $(2.6 \mathrm{~m})$ may result from the presence of an eolian dune on the hanging-wall (Fig. 12), leading to an underestimation of the real offset. Besides these two values, the topographic profiles show a homogeneous deformation along the fault with an average offset of about $4 \mathrm{~m}$. If we assume that this deformation is post late Pleniglacial, the average displacement rate is higher along this fault than along the peel boundary fault. However, it is very likely that the $4 \mathrm{~m}$ offset partly corresponds to a remnant offset (i.e. older than late Pleniglacial). The emplacement of the late Pleniglacial sandsheet from the West has induced a differential coverage in the RVG and the peel block, controlled by the morphology. Consequently, we propose that the peel boundary fault scarp was leveled during the late Pleniglacial, whereas the scarp of the 2nd peel boundary fault was only smoothened. The displacement rates inferred from the offset values then correspond to an overestimation, which cannot be quantified.

\section{Discussion}

From the geometry of the active faults, Van den Berg et al. $(1994,2002)$ and Camelbeeck and Meghraoui (1998) have proposed a strike slip motion along the border faults of the RVRS. Van den Berg et al. (2002) consider the PBFZ as a left lateral strike slip fault zone and the FFZ as characterized by a right lateral motion. In contrast, Camelbeeck and Meghraoui (1998) interpret the en echelon pattern of the FFZ as the result of left lateral extension. These interpretations are in disagreement and they do not fit with the NE-SW direction of extension deduced from the analysis of earthquake focal mechanisms (Plenefish and Bonjer, 1997).

Although the DEM analysis reveals a fault geometry compatible with a strike slip motion of the major faults, the vertical displacement of passive markers like eolian dunes and the limit of fluvial terraces indicates a pure normal faulting mode for the late Quaternary period, related to a NE-SW extension. This apparent paradox can be solved taking into account the role of the structural inheritance in the location and the geometry of the active faults. It has been recently shown that the orientation of the active faults during the Mesozoic and the Cenozoic periods was identical whatever the paleostress field (i.e., Triassic extension, Late Cretaceous N-S compression, Miocene NE-SW extension) (Michon et al., 2003). The age of the structural inheritance is at least Carboniferous and most likely Caledonian (Thorne and Watts, 1989; Houtgast et al., 2002). As these geological events were characterized by the development of large NW-SE strike slip faults (i.e., the Peel Boundary fault and the Feldbiss fault), the fault pattern, which is reactivated in normal faulting mode during the Quaternary is similar to a strike slip fault pattern.

In the different areas, the orientation of the active fault slightly differs (Fig. 6). In the Sittard area, the 
faults are grouped in a single N130-135 oriented trend, whereas in the Uden area, three distinct directions are distinguished (i.e., N110-120, N135-140 and N155-165). Integration of the geometry of the Miocene faults makes it possible to explain this difference. For the Miocene period, the border faults of the southeastern part of the RVRS are characterized by a constant NW-SE direction (Fig. 13). In contrast, the PBFZ in the North-West is composed of the peel boundary fault itself and by N110-120 oriented oblique faults, which have partly controlled the graben subsidence during the Miocene (Michon et al., 2003). The coeval activity of the different fault trends during the Miocene and the Quaternary suggests (1) that the Miocene structural inheritance has controlled the development of the Quaternary faults and (2) there was a similar stress field for the Miocene and Quaternary periods. The superposition of the Miocene and Pleistocene depocentres strongly supports this interpretation. Finally, one can note in our study the lack of the NE-SW trend determined by Van den Berg et al. (1994) and Houtgast and Van Balen (2000) from a $100 \mathrm{~m}$ step DEM. The lack of such an orientation is confirmed by inspection of seismic lines, which show that the Mesozoic and Cenozoic sedimentation is never affected by NE-SW faults. Apparently, the
NE-SW lineaments represent other geomorphic features, like eolian ridges.

The use of high precision DEM has allowed determination of displacement rates along the PBFZ and the FFZ. In the Sittard area, the global displacement rate for the FFZ (i.e., the Geelen fault and the Feldbiss fault) shows small-scale lateral variations ranging from $50 \mathrm{~mm} / \mathrm{ky}$ in the SE (the Caberg-2 terrace) up to $62.2 \mathrm{~mm} / \mathrm{ky}$ in the NW (the Eisden-Lanklaar terrace). Such a variation, which was already recognized by Houtgast et al. (2002), suggests a slightly nonlinear deformation along the FFZ since $330 \mathrm{ka}$. In the northern prolongation of the FFZ, Camelbeeck and Meghraoui (1998) have determined a displacement rate of the same order of magnitude $(80 \pm 40 \mathrm{~mm} / \mathrm{ky})$, which indicates a large-scale constant deformation of the FFZ. In the Roermond area, our study has shown a similar constant deformation along the PBFZ with an average displacement rate of about $65 \mathrm{~mm} / \mathrm{ky}$. This displacement rate drastically increases in the northern segment of the PBFZ (Uden area) where it reaches an average value of $184 \mathrm{~mm} / \mathrm{ky}$. We have already shown in a previous section that fluvial erosion in the Uden area could have disturbed the scarp geometry and in consequence the determination of the displacement rate. However, two independent studies based on the reconstructed

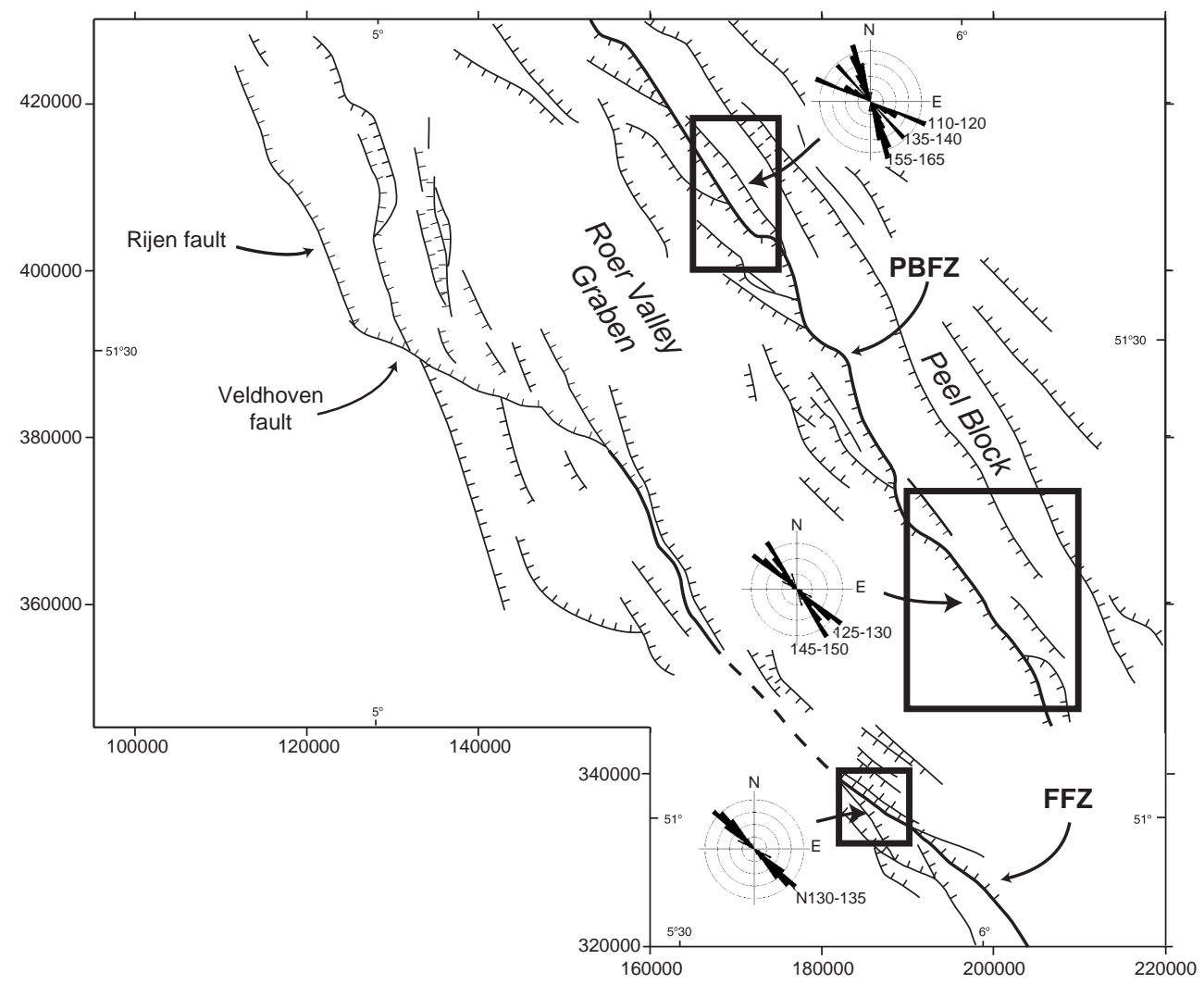

Fig. 13. Comparison of the geometry of the Miocene faults of the RVRS and the orientation of the Quaternary faults determined in the studied areas from the DEM analysis. 
Holocene paleogroundwater levels along the Rhine and Meuse rivers (north of the Uden area; Stouthamer and Berendsen, 2000) and the distribution of a fluvial unit containing pumices from the Laacher See eruption (11063 BP; Verbraeck, 1990) have revealed similar displacement rates of the PBFZ (between 130 and $300 \mathrm{~mm} / \mathrm{ky}$, and $181 \mathrm{~mm} / \mathrm{ky}$, respectively). In addition, a recent study by Cohen et al. (2003) of the deformation of the top of the late Pleniglacial terrace by one of the faults of the PBFZ, probably the 2nd peel boundary fault, gave a time-averaged displacement rate of $60 \mathrm{~mm} /$ ky. Consequently, the high displacement rate values obtained from the DEM analysis are real and they represent a strong increase of the deformation along the northern segment of the PBFZ.

We propose to explain these displacement rate differences by taking into account the large-scale geometry of the RVRS. First the RVRS has a different geometry in the northwestern and southeastern parts (Fig. 2). In the south-east, the graben is nearly symmetric and the deformation is accommodated by two main border faults (the PBFZ and the FFZ). The structural profile determined from seismic sections shows that the PBFZ was more active (i.e., larger offset of the base of the Miocene formation) than the FFZ since the beginning of the Miocene. For the Quaternary period, we also demonstrate that the PBFZ is around $20-30 \%$ more active than the FFZ. In the north-west, this geometry changes. The RVRS is from a structural point of view an asymmetric graben bounded by only one major fault, the PBFZ, which accommodates the main deformation. With a similar amount of extension, the displacement rate along the northern segment of the PBFZ (around $184 \mathrm{~mm} / \mathrm{ky}$ ) should roughly correspond to the sum of the displacement rates along the PBFZ and the FFZ in the southeastern part (around $120 \mathrm{~mm} / \mathrm{ky}$ ). The difference suggests that another mechanism occurred.

The distribution of the Neogene sediments shows the development of a main Neogene depocentre in the northwestern part of the RVRS with the accumulation of $1200 \mathrm{~m}$ of sediments (Fig. 14). During the same period, the subsidence was $33 \%$ less active in the southeastern part with the deposition of around $800 \mathrm{~m}$ of sediments. During the Quaternary, the evolution continued with the superposition of the Miocene and Quaternary depocentres (Houtgast and Van Balen, 2000). Assuming that the development of the depocentre is linked to a larger amount of extension in the northwestern part than in the southeastern half, the deformation accommodated by border faults should be more important in the north-west than in the south-east. The difference between the displacement rates determined for the northwestern and southeastern parts is around $35 \%(184 \mathrm{~mm} / \mathrm{ky}$ in the north-west and $120 \mathrm{~mm} /$ ky in the south-east). The nearly similar values for the difference of the subsidence and for the displacement rate difference suggest that the subsidence in the RVRS is mainly fault-controlled. The same conclusion was made by Houtgast and Van Balen (2000) based on analyses of the bore-hole record in the RVRS. Thus, the different displacement rates determined for each studied area can be explained by the contribution of the large scale-geometry and a differential extension between the northwestern and southeastern parts of the RVRS.

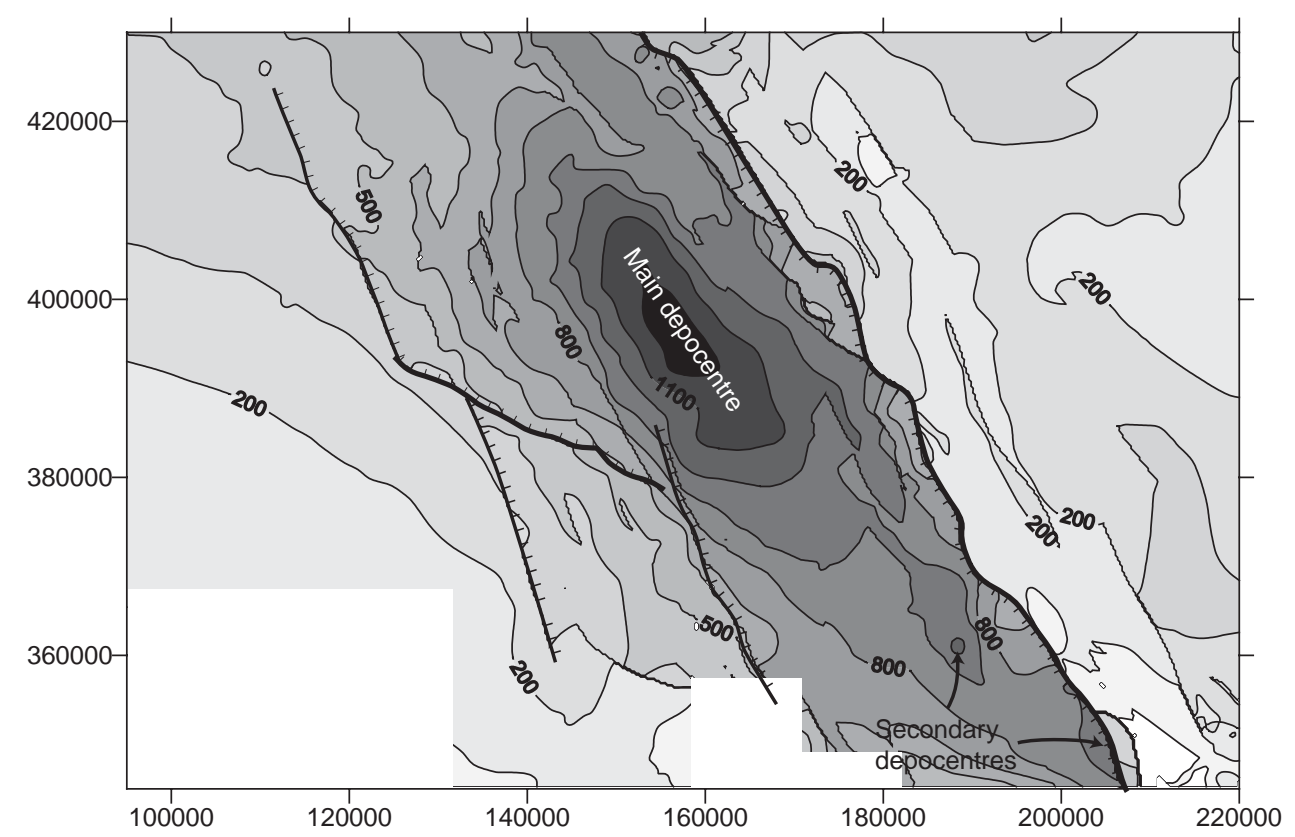

Fig. 14. Thickness map of the Neogene sedimentation showing the location of the main depocentre. The numbers indicate the thickness of Neogene sediments. Only the border faults are represented. 


\section{Conclusion}

The active faulting of the RVRS was studied with a high precision DEM. We show that the use of such a DEM is essential to determine and quantify the neotectonics of the province. The geometry of the active faults, which is compatible with strike-slip motion, results from the interaction between the present-day stress field and the Paleozoic and Mesozoic structural inheritance. The vertical displacement, which affects the Quaternary geological formation along the FFZ and the PBFZ reveals that the border faults of the RVRS are characterized by a pure normal faulting mode without significant lateral motion. In consequence, we claim that the present-day stress field is responsible for a NE-SW extension (perpendicular to the graben). This direction of extension is similar to the one obtained from the analysis of the earthquake focal mechanisms (Plenefisch and Bonjer, 1997). In the graben, the superimposition of the Miocene and Quaternary depocentres suggests that this stress field was constant since the beginning of the Miocene. At a regional scale, the RVRS Miocene to present-day stress field could be explained by the leftlateral motion of the upper Rhine graben induced by a general NW main compression direction associated with the collision between the African and Eurasian plates (Fig. 16 in Michon et al., 2003).

The displacement rate values determined along the FFZ and the PBFZ show that the northwestern part of the RVRS is significantly more active than the southeastern part. The difference may result from the combination of a differential amount of extension between the northwestern and southeastern parts and a different large-scale geometry of the graben in the North-West (half-graben) and the South-East (full-graben).

\section{Acknowledgements}

This publication is a contribution of the Environmental Tectonic (ENTEC) European Project funded by EU (RTN-1999-00003). We thank Rob Houtgast and Kees Kasse for fruitful discussions. The Survey Department of the Ministry of Transport, Public Works and Water Management of the Netherlands, owner of the DEM data, kindly permitted the publication of the DEM figures.

\section{References}

Bisschops, J.H., 1973. Toelichtingen bij de geologische kaart van Nederland 1:50.000, blad Eindhoven Oost (51O). Rijks Geologische Dienst, Haarlem.

Camelbeeck, T., Meghraoui, M., 1998. Geological and geophysical evidence for large scale palaeo-earthquakes with surface faulting in the Roer Graben (northwest Europe). Geophysical Journal International 132, 347-362.

Cohen, K., Gouw, M.J.P., Holten, J.P., 2003. Fluvio-deltaic floodbasin deposits recording differential subsidence within a coastal prism (central Rhine-Meuse delta, the Netherlands). In: Blum, M. et al. (Eds.), Fluvial Sedimentology VII, Special Publication 35. International Association of Sedimentologists, Blackwell, pp. $\mathrm{xx}-\mathrm{xx}$.

Davy, Ph., Cobbold, P., 1991. Experiments on shortening of 4-layer continental lithosphere. Tectonophysics 228, 255-274.

Felder, W.M., Bosch, P.W., Bisschops, J.H., 1989. Geologische kaart van Zuid-Limburg en omgeving, schaal 1:50.000. Afzettingen van de Maas. Rijks Geologische Dienst, Haarlem.

Geluk, M.C., Duin, E.J., Dusar, M., Rijkers, R.H., van Denberg, M.W., van Rooijen, P., 1994. Stratigraphy and tectonics of the Roer Valley Graben. Geologie en Mijnbouw 73, 129-141.

Houtgast, R.F., Van Balen, R.T., 2000. Neotectonics of the Roer Valley Rift System, the Netherlands. Global Planetary Change 27, 131-146.

Houtgast, R.F., Van Balen, R.T., Bouwer, L.M., Brand, G.B.M., Brijker, J.M., 2002. Late Quaternary activity of the Feldbiss Fault Zone, Roer Valley Rift System, the Netherlands, based on displaced fluvial terrace fragments. Tectonophysics 352, 295-315.

Houtgast, R.F., Van Balen, R.T., Kasse, C., Vandenberghe, J., 2003. Late Quaternary tectonic evolution and aseismic near surface fault displacements along the Geleen Fault (Feldbiss Fault Zone-Roer Valley Rift System, the Netherlands), based on trenching. Netherlands Journal of Geosciences/Geologie en Mijnbouw 82, xx-xx.

Huisink, M., 2000. Changing river styles in response to Weichselian climate changes in the eastern Netherlands. Sedimentary and Geology 133, 115-134.

Huxtable, J., Aitken, J., 1985. Thermolimunescence dating results for the Palaeolithic site Maastricht-Belvédère-Meded. Rijks Geologische Dienst 39, 41-44.

Kasse, C., 1997. Cold-climate aeolian sand-sheet formation in NorthWestern Europe (c. 14-12.4 Ka); a response to permafrost degradation and increased aridity. Permafrost and Periglacial Processes 8, 295-311

Kasse, C., 1999. Late Pleniglacial and Late Glacial aeolian phases in The Netherlands. In: Schirmer, W. (Ed.), Dunes and fossil soils; GeoArchaeoRhein 3, 61-82.

Kooi, H., Cloetingh, S., Remmelts, G., 1991. Lithospheric dynamics and the rapid Pliocene-Quaternary subsidence phase in the Southern North Sea Basin. Tectonophysics 192, 245-259.

Michon, L., Van Balen, R.T., Merle, O., Pagnier, H., 2003. The Cenozoic evolution of the Roer Valley Rift System integrated at a European scale. Tectonophysics 367, 101-126.

Mücher, H.J., 1986. Aspects of loess and loess-derived slope deposits: an experimental and micromorphological approach. Fysisch Geografisch en Bodemkundig Laboratorium, Universiteit van Amsterdam, pp. 267.

Paulissen, E., 1973. De morfologie en de Kwartairstratigrafie van de Maas vallei in Belgisch Limburg-Verh. Kon. Acad. Wetensch. Lett. en Schone Kunsten. Klassieke Wetenschappen 35 (127), $1-266$.

Plenefish, T., Bonjer, K.P., 1997. The stress field in the Rhine Graben area inferred from earthquake focal mechanisms and estimation of frictional parameters. Tectonophysics 275, 71-97.

Rijks Geologische Dienst, 1983. Geomorfologische kaart van Nederland 1:50.000, blad 45. Rijks Geologische Dienst, Haarlem.

Rijkswaterstaat, 2000. Productspecificatie AHN 2000. Report of the Survey Department of the Ministry of Transport, Public Works and Water Management of the Netherlands.

Stouthamer, E., Berendsen, H.J.A., 2000. Factors controlling the Holocene alvulsion history of the Rhine-Meuse Delta (the Netherlands). Journal of Sedimentary Research 70, 1051-1064. 
Thorne, J.A., Watts, A.B., 1989. Quantitative analysis of North Sea subsidence. AAPG Bulletin 73, 88-116.

Van Balen, R.T., Houtgast, R.F., Van der Wateren, F.M., Vandenberghe, J., Bogaart, P.W., 2000. Sediment budget and tectonic evolution of the Meuse catchment in the Ardennes and the Roer Valley Rift System. Global Planetary Change 27, 113-129.

Van den Berg, M.W., 1989. Geomorfologische kaart van Nederland 1:50.000 kaartblad 59 Genk, 60 Sittard, 61 Maastricht, 62 Heerlen, met toelichting en de kaart Maasterrassen en hellingklassen. Staring Centrum, Wageningen en Rijks Geologische Dienst, Haarlem. 32pp.

Van den Berg, M.W., 1994. Neotectonics of the Roer Valley rift system. Style and rate of crustal deformation inferred from syntectonic sedimentation. Geologie en Mijnbouw 73, 143-156.

Van den Berg, M.W., Groenewoud, W., Lorenz, G.K., Lubbers, P.J., Brus, D.J., Kroonenberg, S.B., 1994. Patterns and velocities of recent crustal movements in the Dutch part of the Roer Valley rift system. Geologie en Mijnbow 73, 157-168.

Van den Berg, M.W., Vanneste, K., Dost, B., Lokhorst, A., Van Eijk, M., Verbeeck, K., 2002. Paleoseismic investigations along the peel boundary fault: geological setting, site selection and trenching results. Netherlands Journal of Geosciences/Geologie en Mijnbouw $81,39-60$.

Van den Toorn, J.C., 1967. Toelichtingen bij de geologische kaart van Nederland 1:50.000, blad Venlo West (52W). Rijks Geologische Dienst, Haarlem.

Van Kolfschoten, T., Roebroeks, W., Vandenberghe, J., 1993. The Middle and Late Pleistocene sequence at Maastricht-Belvédère: the type locality of the Belvédère Interglacial. Mededelingen Rijks Geologische Dienst, N.S. 47, 81-91.

Verbraeck, A., 1990. De Rijn aan het einde van de laatste ijstijd: De vorming van de jongere afzettingen van de Formatie van Kreftenheye. Geografisch Tijdschrift Nieuwe Reeks 24, 328-340.

Winstanley, A.M., 1993. A review of the Triassic play in the Roer Valley Graben, SE onshore Netherlands. In: Parker J.R. (Eds.), Petroleum geology of Northwest Europe. Proceedings of the Fourth Conference. Geological Society of London, pp. 595-607.

Ziegler, P.A., 1988. Evolution of the Artic North Atlantic and the western Tethys. American Association Petroleum Geolology Mem. 43, 198pp

Ziegler, P.A., 1990. Geological atlas of western and central Europe. 2nd ed. Shell Internationale Petroleum Mij., distributed by Geological Society of London, Publishing House, Bath, 238p, 56 encl.

Zijerveld, L., Stephenson, R., Cloetingh, S., Duin, E., Van den Berg, M.W., 1992. Subsidence analysis and modelling of the Roer Valley Graben (SE Netherland). Tectonophysics 208, 159-171.

Zonneveld, J.I.S., 1974. The terraces of the Maas (and Rhine) downstream of Maastricht. In: L'évolution Quartenaire des Bassins Fluviaux de la Mer du Nord Meridionale, Centenaire de la Société Géologique de Belgique, Liège, pp. 133-157.

Zuidam, R.A., 1980. Het Meinweggebied en Roergebied. Een tektonisch en eolisch beïnvloed terrassenlandschap nabij Roermond (Midden Limburg). Geografisch Tijdschrift Nieuwe Reeks 14, 2, 120-133. 